FINAL REPORT

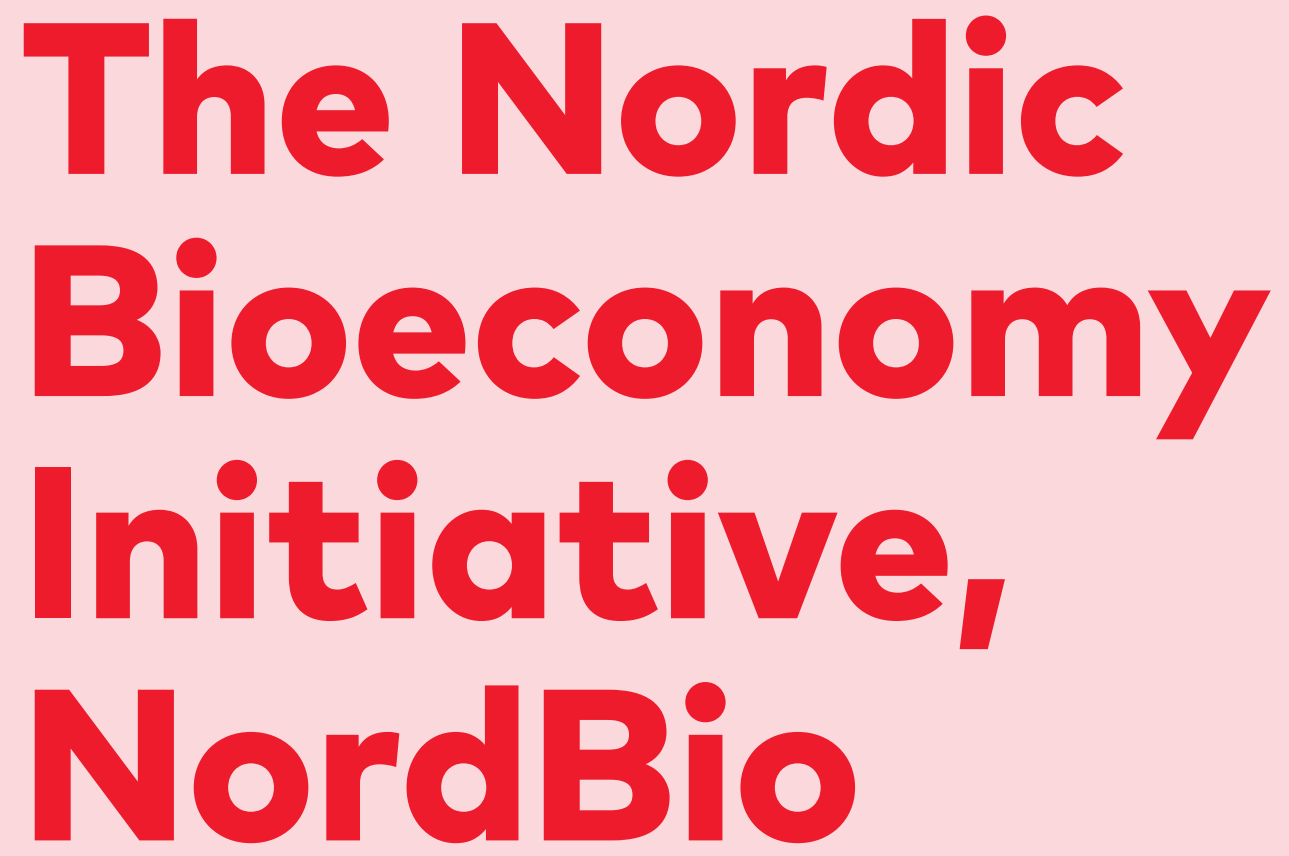

111) Nordic Council of Ministers 



\section{The Nordic Bioeconomy Initiative, NordBio}

Final report

Stefán Gíslason and Hrafnhildur Bragadóttir (editors)

TemaNord 2017:526 
The Nordic Bioeconomy Initiative, NordBio

Final report

Stefán Gíslason and Hrafnhildur Bragadóttir (editors)

ISBN 978-92-893-4970-3 (PRINT)

ISBN 978-92-893-4971-0 (PDF)

ISBN 978-92-893-4972-7 (EPUB)

http://dx.doi.org/10.6027/TN2017-526

TemaNord 2017:526

ISSN 0908-6692

Standard: PDF/UA-1

ISO 14289-1

() Nordic Council of Ministers 2017

Layout: NMR

Print: Rosendahls

Printed in Denmark

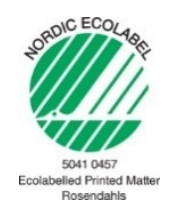

Although the Nordic Council of Ministers funded this publication, the contents do not necessarily reflect its views, policies or recommendations.

\section{Nordic co-operation}

Nordic co-operation is one of the world's most extensive forms of regional collaboration, involving Denmark, Finland, Iceland, Norway, Sweden, the Faroe Islands, Greenland, and Åland.

Nordic co-operation has firm traditions in politics, the economy, and culture. It plays an important role in European and international collaboration, and aims at creating a strong Nordic community in a strong Europe.

Nordic co-operation seeks to safeguard Nordic and regional interests and principles in the global community. Shared Nordic values help the region solidify its position as one of the world's most innovative and competitive. 


\section{Contents}

Preface.

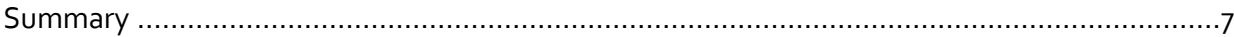

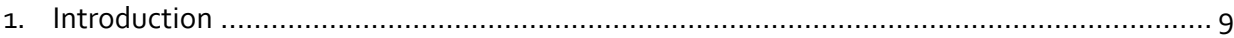

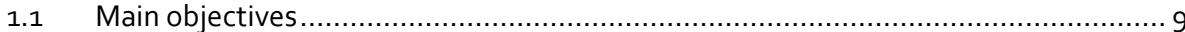

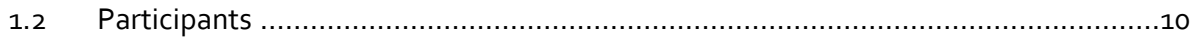

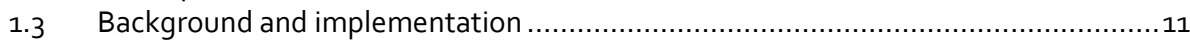

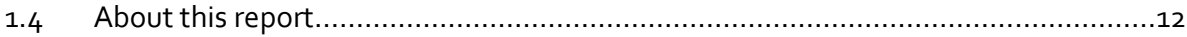

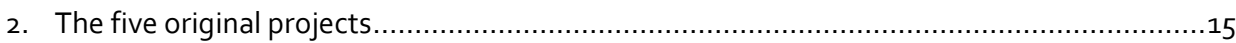

2.1 The Biophilia Educational Project - creativity in the classroom ….......................15

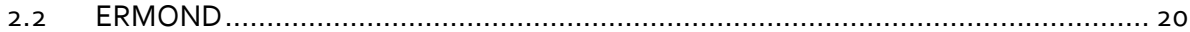

2.3 Innovation in the Nordic Bioeconomy........................................................... 24

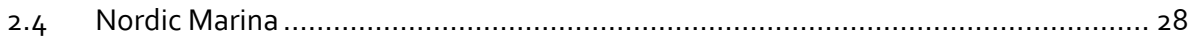

2.5 WoodBio: Wood biomass in the Nordic Bioeconomy ........................................ 31

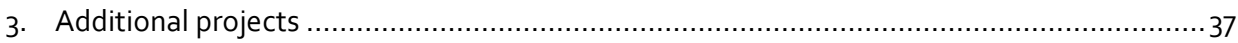

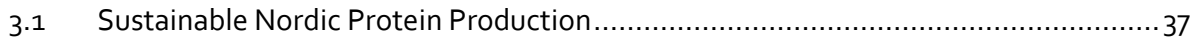

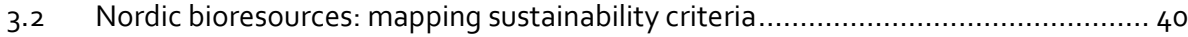

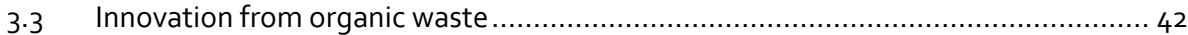

3.4 Regional economic impact and potential of Nordic Bioeconomy .......................... 46

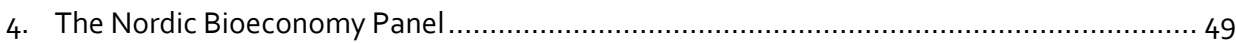

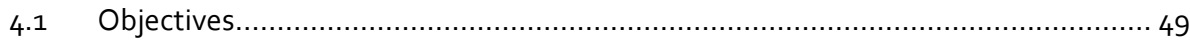

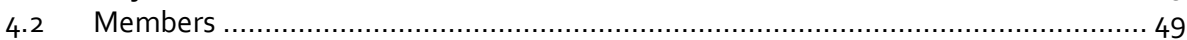

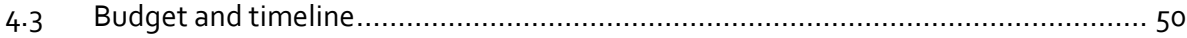

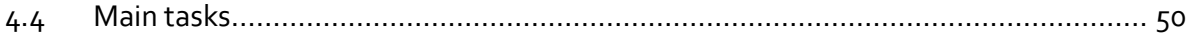

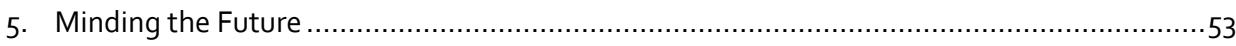

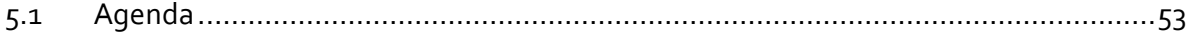

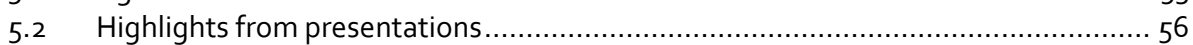

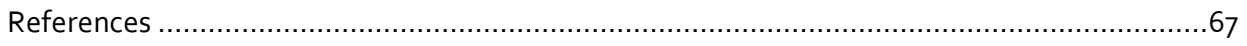

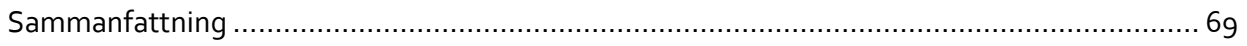





\section{Preface}

The Nordic Bioeconomy Initiative, NordBio, was a cooperation program launched under Iceland's presidency of the Nordic Council of Ministers in 2014. Based on the vision of a Nordic lead in green growth and bioeconomy, the program aimed to accelerate the development of a sustainable bioeconomy in the Nordic countries, and to enhance Nordic influence on European and global bioeconomy policies.

In implementing the program, strong emphasis was placed on a cross-sectoral and cross-ministerial cooperation. As a result, five Nordic Councils of Ministers and three governmental ministries in Iceland were involved in carrying out the program's mandate. This interdisciplinary approach was also reflected in the many projects that were performed under NordBio's umbrella, each focusing on a different theme and designed to bring together information and expertise from all the Nordic countries.

Another important result of this cooperation was the establishment of the Nordic Bioeconomy Panel, a multidisciplinary consultation venue tasked with developing a common Nordic bioeconomy strategy. The strategy, which is expected to be finalised before the end of 2017, will draw on experiences gained in a variety of sectors in all the Nordic countries. It will lead the way for continued and increasingly effective cooperation of the Nordic countries, and further strengthen the Nordic position as a global frontrunner within the bioeconomy.

The successful outcomes of the NordBio projects, including the large-scale educational project Biophilia, demonstrate clearly the significant potential that lies in bringing Nordic experts together to achieve common bioeconomy goals. Overall, the program provided a valuable exercise to strengthen the dialogue and cooperation between the Nordic countries on a range of issues, including sustainable utilisation of living natural resources, reduction of waste, innovation and education.

In addition to the projects directly linked to the program itself, NordBio has served as an inspiration for various other bioeconomy initiatives, both on national and Nordic level, and has helped in placing the bioeconomy higher on the political agenda in the Nordic countries. This development seems likely to continue; a clear 
sign thereof is the fact that since the launch of NordBio under Iceland's presidency in 2014, bio-economy goals have made their way into the program of every Nordic country holding presidency in the Nordic Council of Ministers.

Our hope is that this work and the projects that have been carried out as a part of it will be an inspiration for ongoing work and growing emphasis on sustainable use of living resources in our economies.

February 2017

Halldór Runólfsson

Chairman of the Icelandic Program

Steering Group for NordBio 


\section{Summary}

The Nordic Bioeconomy Initiative, NordBio, was a cooperation program involving the following five Nordic Councils of Ministers: Fisheries and Aquaculture, Agriculture, Food and Forestry (MR-FJSL); Environment (MR-M); Trade, Energy and Regional Policies (MR-NER); Education and Research (MR-U); and Culture (MR-K). The program was launched during the Icelandic presidency of the Nordic Council of Ministers in 2014 and covered three years (2014-2016).

The goal of the NordBio program was to make the Nordic countries leading in the global development of the bioeconomy. The program was furthermore intended to stimulate the development and improvement of sustainable production and utilisation of products, reduce strain on the environment, strengthen education, knowledge and research in the field of the bioeconomy, promote innovation in energy efficiency, food safety and public health, and encourage Nordic cooperation.

Several projects were carried out under the umbrella of NordBio, supporting its objectives. The projects focused on a sustainable utilisation of the living natural resources and on facilitating the structuring of a competitive economy, as well as the development of new methods in youth education. The following projects were the five "original" or "main" NordBio projects:

The Biophilia Educational Project - creativity in the classroom. A large-scale pilot project which aimed to inspire children to explore their own creativity while learning about music, nature and science through new technologies.

ERMOND. A project aimed at facilitating new thinking and seeking new solutions to increase ecosystem resilience to prevent damage and loss of lives due to natural hazards in the Nordic countries.

Innovation in the Nordic Bioeconomy. A project intended to have direct economic impact through innovation and value-creation in the Nordic Bioeconomy and strengthen regional and economic growth.

Nordic Marina. The goal of this project was to reduce emissions and increase the use of alternative fuels in the marine sector.

WoodBio. A project which aimed to highlight the role of forestry in the Nordic Bioeconomy with emphasis on wood biomass as raw material.

A number of other projects and initiatives were carried out under the umbrella of the NordBio program, including a project aimed to map plant protein supply for the Nordic food and feed industry, a project with the goal of identifying Nordic bioresources and review their management, a project created to stimulate innovation and value creation from biodegradable waste, and a project focusing on regional economic impact and the potential of the Nordic bioeconomy.

In addition to these projects, the NordBio initiative included the establishment of a Nordic Bioeconomy Panel, a multidisciplinary consultation venue tasked with 
developing a common Nordic bioeconomy strategy, along with promoting and coordinating Nordic cooperation within the bioeconomy.

The closing conference of the NordBio program "Minding the Future - Bioeconomy in a Changing Nordic Reality" took place in Reykjavik, Iceland on 5-6 October 2016. The conference brought together experts on the bioeconomy with diverse backgrounds and from various countries. The purpose of the conference was to offer an informative and inspiring dialogue, present the outcomes of the NordBio projects, discuss challenges and opportunities ahead and to sow new seeds for the future. 


\section{Introduction}

The Nordic Bioeconomy Initiative, NordBio, was a cooperation program launched during the Icelandic presidency of the Nordic Council of Ministers in 2014. The NordBio program covered three years, 2014-2016, and involved the following five Nordic Councils of Ministers: Fisheries and Aquaculture, Agriculture, Food and Forestry (MR-FJSL); Environment (MR-M); Trade, Energy and Regional Policies (MR-NER); Education and Research (MR-U); and Culture (MR-K). The program was intended to bring together Nordic experts in these fields to work on projects promoting sustainable utilisation of living natural resources, with focus on the interests of both society and the environment. Moreover, the aim was to facilitate the structuring of a competitive economy, to enable the Nordic collaboration to make a greater impact on European and global policy, and to improve the common Nordic position in the competition for European research funding, thus helping the Nordic countries to gain ground in global markets.

\section{$1.1 \quad$ Main objectives}

Bioeconomy has over the course of the last decade become a widely used term in global policies related to various issues, such as food security, sustainable production, and energy needs. It typically refers to the need for new thinking to solve today's pressing environmental, social and economic challenges. The concept has strong ties to efforts aimed at transforming the traditional fossil fuel driven economy into a resourceefficient economy based on sustainability principles and increased use of renewable resources. Among the objectives of the bioeconomy are the reduction of climate change impact, reduced use of raw materials and energy, increased added value from biomaterials, and increased utilisation of waste (Smáradóttir et al., 2015).

The goal of the NordBio program was to make the Nordic countries leading in the global development of the bioeconomy. More specifically, the program was intended to achieve the following objectives:

- Develop and improve methods of sustainable production and utilisation of products in order to stimulate innovation and economy, and to reduce strain on the environment in the Nordic countries.

- Strengthen knowledge that is beneficial in policy-making in economic and environmental affairs by increasing collaboration in research, development, and innovation. 
- Strengthen innovation in energy efficiency, food safety and public health, and facilitate Nordic production in markets to meet the growing need for food as the world's population increases.

- Report the achievements of projects in the field of education for sustainable development.

- Make research and academic work in the fields of sustainable production and utilisation more attractive to future generations.

- Bring together science, technology, education and culture at various school levels.

- Offer a joint Nordic venue and platform for cooperation, collaboration, and exchange of views across ages and fields of expertise.

Figure 1: The NordBio logo.

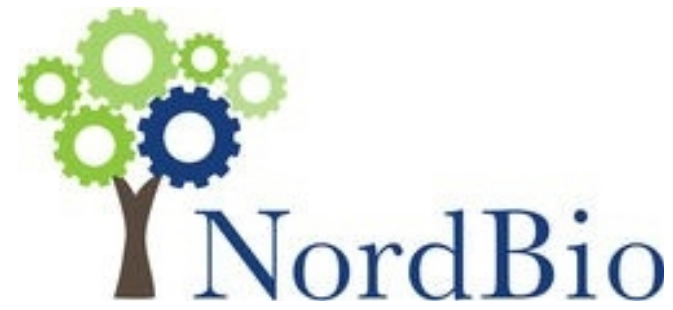

\subsection{Participants}

The Nordic Council of Ministers for Fisheries and Aquaculture, Agriculture, Food and Forestry (MR-FJLS) was responsible for the implementation of the program, in cooperation with the Nordic Councils of Ministers for the Environment (MR-M), Trade, Energy and Regional Policies (MR- NER), Education and Research (MR- U), and Culture (MR-K). The implementation of the program therefore required close multidisciplinary collaboration.

Three governmental ministries in Iceland, and the collaboration network under whose umbrella they fall, worked together under Iceland's chairmanship program on improving conditions for the Nordic bioeconomy. The Icelandic ministries in question were the Ministry of Industries and Innovation, the Ministry for the Environment and Natural Resources, and the Ministry of Education, Science and Culture. An Icelandic Program Steering group (IPSG) was established by the three Ministries, consisting of the following members:

- Mr. Halldór Runólfsson, Ministry of Industries and Innovation (chair).

- Mr. Sveinn Porgrímsson / Mr. Elvar Knútur Valsson. Ministry of Industries and Innovation.

- Mr. Jón Geir Pétursson, Ministry for the Environment and Natural Resources.

- Mr. Stefán Stefánsson, Ministry of Education, Science and Culture. 
The group was assisted by a steering group coordinator, Mrs. Hólmfríður Sveinsdóttir.

A Nordic Steering Group (NSG) was also established to strengthen the Nordic dimension of the project. The NGS consisted of representatives from all the Nordic Countries, chaired by Mrs. Danfríður Skarphéðinsdóttir.

\subsection{Background and implementation}

The three-year NordBio program was the largest of three priority programs under Iceland's presidency of the Nordic Council of Ministers in 2014. The program was built on the components of recent national, Nordic, EU, and global policies. It was, moreover, based on the Nordic Bioeconomy Initiative 2013-2018, the Framework Program for Nordic Co-operation in Fisheries and Aquaculture, Agriculture, Food and Forestry 2013-2016, and the Nidaros Declaration, adopted at the meeting of the Nordic Council of Ministers for Fisheries and Aquaculture, Agriculture, Food and Forestry (MR-FJLS) on 28 June 2012 in Trondheim, Norway.

The budget for the program was initially adopted at a meeting of the Ministers for Nordic Cooperation (MR-SAM) on 2 July 2013, when DKK 10,000,000 were granted for the first year of the program, 2014. Additional DKK 10,000,000 were granted at subsequent MR-SAM meetings for each of the remaining years of the program, 2015 and 2016, resulting in a total budget of DKK 30,000,000. Just over DKK 21,000,000 of the total budget were earmarked to the five main NordBio projects, with Biophilia and Innovation in the Nordic Bioeconomy receiving the largest shares.

The program's Mandate was adopted on 31 January 2014, and a kick-off meeting was held in Reykjavík on 5 February 2014, attended by over 100 participants from all the Nordic countries, including government officials, representatives from Icelandic and Nordic institutions, universities and research centres. The five main NordBio projects were introduced at the meeting, and presentations given on the role of Nordic institutions in these projects, the future development of the bioeconomy and the importance of a bioeconomy internationally.

The Icelandic Program Steering Group (IPSG) had the role of launching the NordBio Program, as well as supervising and ensuring the quality of the program and its focus on the Mandate's priorities. The IPSG had a consultative role, developed proposals for the Nordic Steering Group (NSG) on budget, administration of the program etc., and provided oversight of the use of funds. The Nordic Council of Ministers' Committee of Senior Officials for Fisheries and Aquaculture (EK-FJLS) had the authority to make final decisions on funding and other fundamental issues regarding the program. 


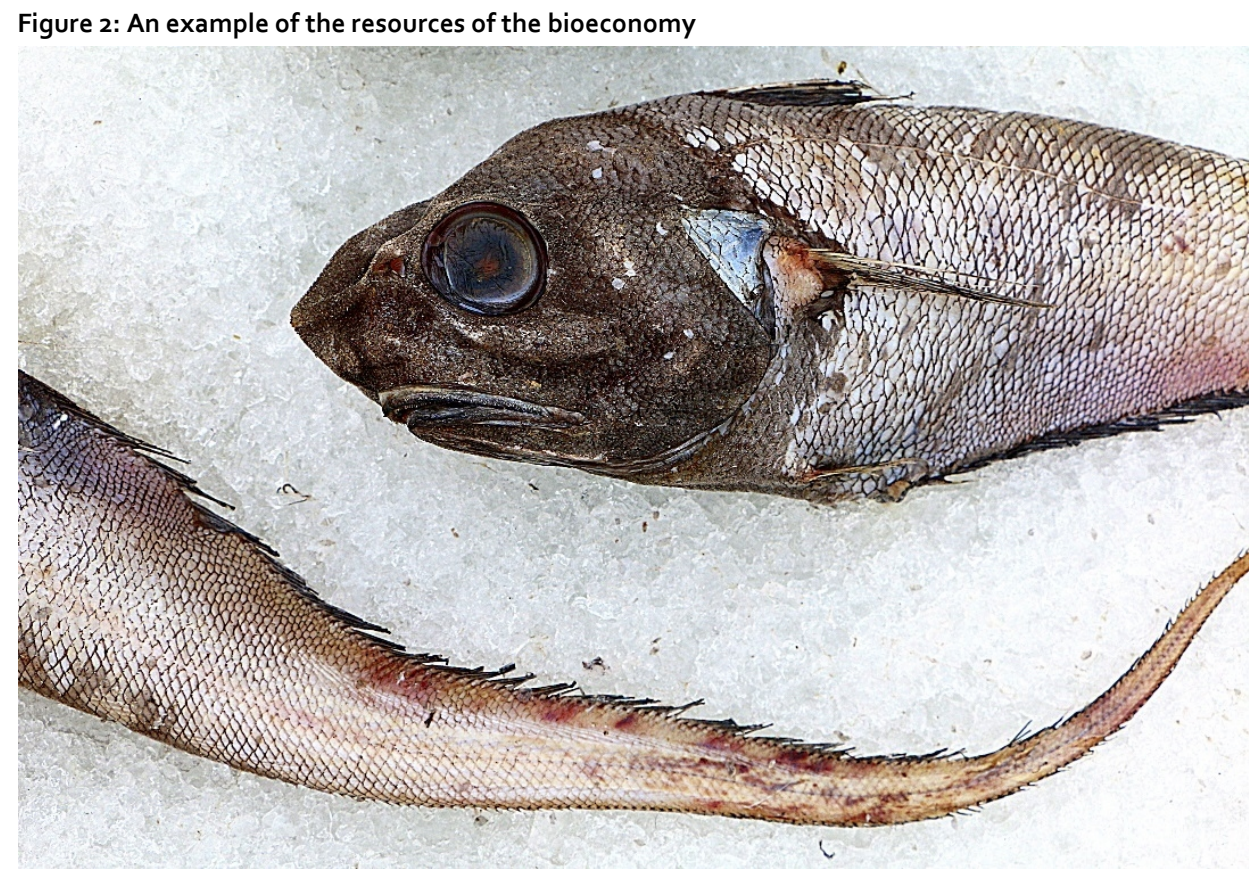

Source: Hugi Ólafsson.

\subsection{About this report}

This report is the final report of the NordBio program. It contains a summary of the main outcomes of the program, including its projects, the Nordic Bioeconomy Panel, and the closing conference of the program. Chapters 2 describes the projects that were performed under the program's umbrella, usually referred to as the "main projects". Chapter 3 adds description of four of the additional, or "smaller", NordBio projects. Chapter 4 outlines the mandate and structure of the Nordic Bioeconomy Panel. Finally, Chapter 5 provides highlights of the program's closing conference "Minding the Future - Bioeconomy in a Changing Nordic Reality", held in Reykjavík, Iceland on 5-6 October 2016.

The report is partly based on texts previously published at the websites of the Nordic Council of Ministers ${ }^{1}$ and the Nordbio program. ${ }^{2}$ In addition, the following experts contributed to the report:

- Anna Berlina, Nordregio.

- Anna Margrét Kornelíusdóttir, Icelandic New Energy.

- Anna María Ágústsdóttir, Soil Conservation Service of Iceland.

${ }^{1}$ http://www.norden.org/en/theme/nordic-bioeconomy

${ }^{2}$ http://nordbio.org/ 
- Arnfriður Valdimarsdóttir, Ministry of Education, Science and Culture, Iceland.

- Auður Rán Porgeirsdóttir, Ministry of Education, Science and Culture, Iceland.

- Árni Bragason, Soil Conservation Service of Iceland.

- Brynhildur Davíðsdóttir, University of Iceland.

- Danfriður Skarphéðinsdóttir, Ministry for the Environment and Natural Resources.

- Guðmundur Halldórsson, Soil Conservation Service of Iceland.

- Halldór Runólfsson, Ministry of Industries and Innovation, Iceland.

- Hólmfríđur Sveinsdóttir, NordBio program coordinator.

- Hörður Kristinsson, Matís.

- Ingunn Gunnarsdóttir, Environment Agency of Iceland.

- Liv la Cour Belling, Nordic Council of Ministers.

- Ólafur Eggertsson, Iceland Forest Service.

- Sigrún Elsa Smáradóttir, Matís.

- Sveinn Margeirsson, Matís.

- Póra Valsdóttir, Matís. 



\section{The five original projects}

Several projects have been carried out under the umbrella of NordBio, supporting its objectives. The greatest emphasis has been on five of these, which are usually referred to as "the main projects". An overview of these five projects will be given in the following sections, explaining their goals and the main outcomes.

\subsection{The Biophilia Educational Project - creativity in the classroom}

The Biophilia Educational Project is a large-scale pilot project that builds on the participation of academics, scientists, artists, teachers and students at all academic levels. The project was originally developed by Björk Guðmundsdóttir, the City of Reykjavík and the University of Iceland, in relation to the release of Björk's 2011 album Biophilia. In connection with its 2014 chairmanship of the Nordic Council of Ministers, the Icelandic government sought collaboration with the other Nordic countries to further develop the project and local cooperation networks were set up in all the Nordic countries.

The Biophilia Educational Project aims to inspire children to explore their own creativity, while learning about music, nature and science through new technologies. Students learn through hands-on participation, composition and collaboration. Participants acquire the skills to develop their musical imagination, to push their creative boundaries and make music in an impulsive and responsive way, inspired by the structures and phenomena of the natural world.

The project presents an example of a dynamic collaboration between different sectors of society, such as educational systems, cultural institutions, science, and research institutes. It creates a platform for dialogue and debate which encourages both personal and social development, thereby contributing to a sustainable society where new approaches are actively explored. 
Figure 3: Biophilia participants

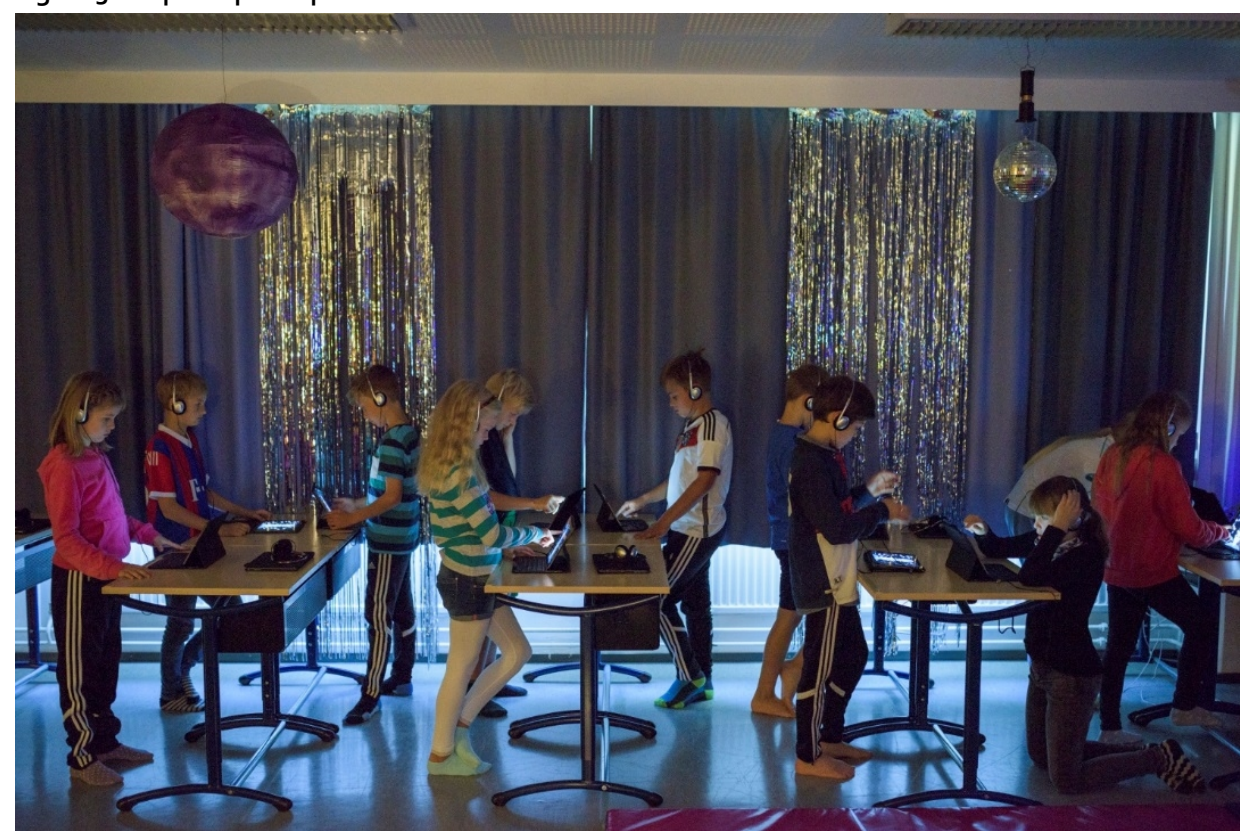

Source: Biophilia Finland.

\subsubsection{Main objectives}

The objectives of the project are:

- to promote innovation in schools through the development of educational methods which combine natural sciences, creativity and technology

- to break up traditional teaching practices through a cross-disciplinary approach, across all ages, subjects, and disciplines

- to set up a Nordic collaborative network that will share experiences and ideas, and further develop the project based on common Nordic values

- to encourage young people's interest in creativity, natural sciences and technology, thus progressively increasing the competitiveness of the Nordic countries.

\subsubsection{The implementation of the project}

Eight countries participated in the project: Denmark, the Faroe Islands, Finland, Greenland, Iceland, Norway, Sweden and the Åland Islands. The participating teachers worked in various educational settings, from preschool to higher education and their age varied from 22 to 66 years old. Approximately 6o\% were women and $40 \%$ men. $50 \%$ of the teachers had been in their current position for more than 10 years and $34.5 \%$ for less than five years. 
The Icelandic team travelled to the 8 participating regions and held Biophilia workshops for the teachers collaborating in the project. Two annual meetings were held for the project managers of each region, a kick-off seminar was held in Iceland in November 2014, and a closing conference was held in October 2016, both attended by over 70 guests from across the Nordic countries.

The Biophilia Educational Project enjoyed widespread publicity in the media, both within and outside the Nordic countries. It has been presented at conferences, for example in Canada, Estonia and the UK.

\subsubsection{Official website and Educational Forum}

An official website was created which serves as an official information site for all interested parties, including the general public. ${ }^{3}$ It contains information on the Nordic collaboration, gives access to the educational material, and provides a general overview and background to the project. The content of the website is available in five languages: Icelandic, Danish, Swedish, Finnish, and English. The education material has been translated into 7 languages: Icelandic, Danish, Norwegian, Swedish, Finnish, Faroese, and English.

A closed website, the Educational Forum, was set up. Participating teachers were invited to share their experiences, thoughts and ideas on the Biophilia Educational Project. The forum was a part of the Nordic collaborative experiment on the development of Biophilia as a teaching and learning tool, intended to work as a place for discussion and networking between Nordic teachers, as well as being a tool for data collection. The forum did not work as intended, and the participants gave several reasons for this; they felt the forum was complicated, they felt they did not have enough time on their hands to give it their proper attention, and many noted that they would have been more comfortable using a pre-existing networking site such as Facebook.

${ }^{3}$ www.biophiliaeducational.org 


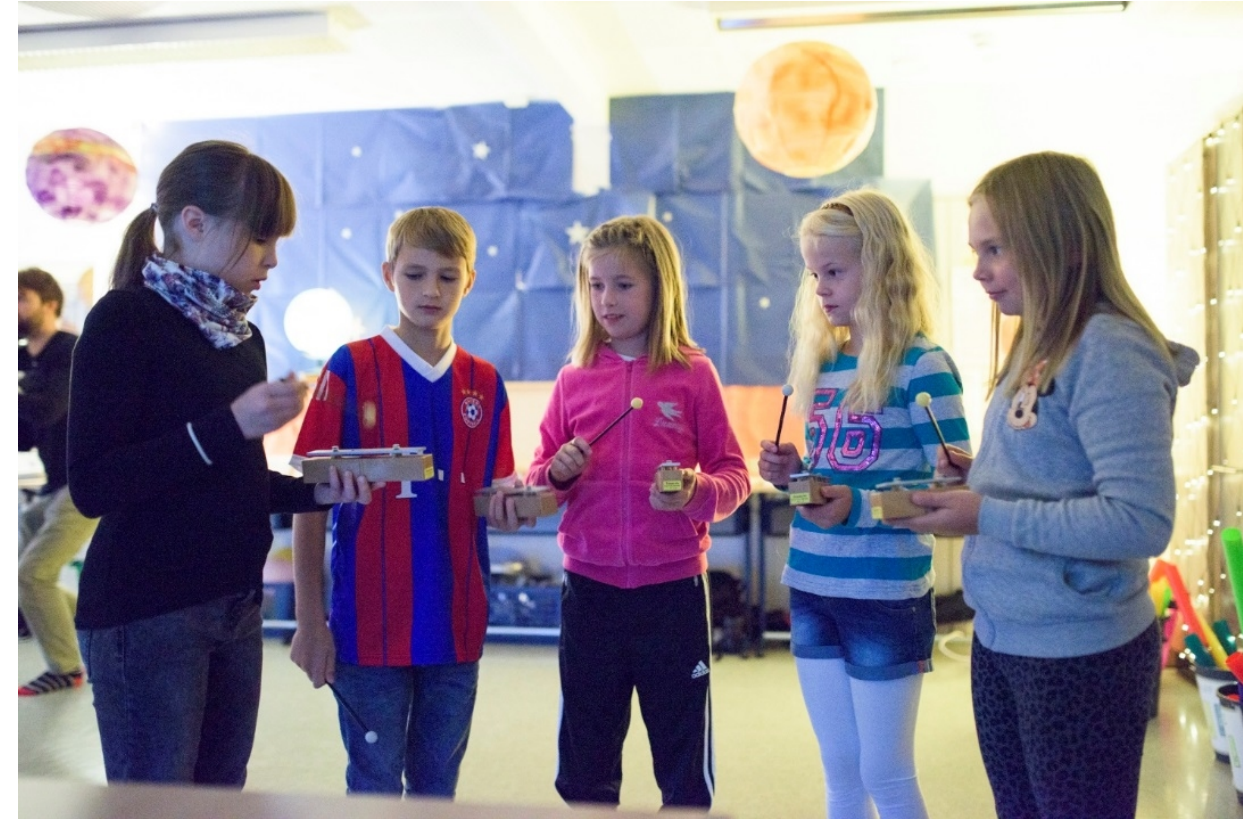

Source: Biophilia Finland.

\subsubsection{The main conclusion}

An independent consultation company was commissioned to evaluate both the implementation and the methodology of the project. The evaluation was intended to assess if and how the main objectives of the project were achieved, what the main strengths and weaknesses were, and what effects the Biophilia Educational Project has had on the participating teachers, and their work, workplace and students.

In general, the teachers were satisfied with the Biophilia Educational Project. The results of surveys and focus groups showed that the project had a positive influence on the teaching methods of all the participating teachers, as well as showing increased interest among them to use a creative approach in their teaching. The results also show an increased interest in integrating different subjects in their teaching and in most of the participating countries the teachers reported an increased interest among their students in music, creative ways of learning, technology and natural science. 


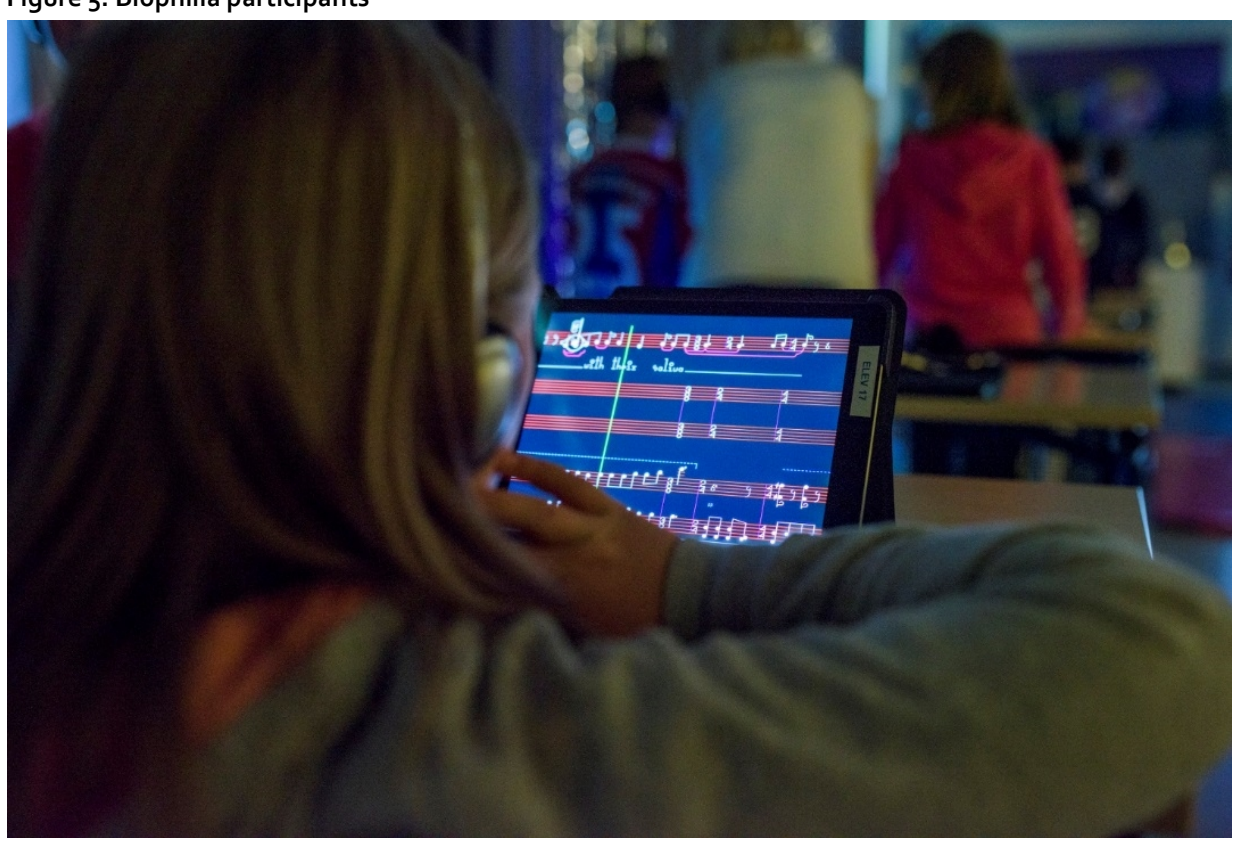

Source: Biophilia Finland.

Based on the results of this evaluation a few recommendations were made on how a project such as this might be improved. It is important to find ways to make it easier for participants to collaborate with each other both within and between countries; information, guidelines and instructions need to be clear and follow-up needs to be provided throughout the project. Participants need to have strong support from their leadership/management as well as support from the municipality.

While participating in the Biophilia Educational Project participants developed many diverse practices and methods. A collection of the teaching guidelines is being assembled and will be published on the project website as well as in an updated Biophilia app.

\section{Quotes from teachers who participated in the project}

"The participation in Biophilia has strengthened the conversation and the real integration of subjects. It has encouraged and inspired teachers, through the experience, to integrate in a more meaningful and effective way. It also has inspired teachers to be creative in their teaching:

- The students became active, creative, curious and had fun

- Teaching became a playing field open to ideas

- Students who normally were weak, not willing to participate or express themselves found their place and flourished, which increased their self-confidence." 
In 2017, Iceland, Norway and Finland will pursue teaching Biophilia. Iceland and Finland also intend to expand the project by introducing it to new schools in different areas of the country.

\subsubsection{The Nordic Knowledge Train}

The Nordic Knowledge Train (NKT) was a side-project of Biophilia. It was a science communication outreach project between Frodskaparsetur Foroya (Faroe Islands), Heureka Science Centre (Finland), Jærmuseet, Science Circus (Norway), and Technichus (Sweden), and coordinated by the University of Iceland. The project aimed at exploring new methods in formal and informal education, and connecting natural sciences, technique, art and innovation across school stages, subjects and sectors. By using outreach methods, the train provided opportunities for reaching remote areas or hard to reach communities, and opening up new possibilities of social inclusion.

Remote areas and hard to reach communities, geographically or socially, benefited from the visits of the train and special measures were taken to meet pupils and parents among fugitives or asylum seekers. The Nordic partners in the project strengthened their network and collaboration opportunities in their local communities, with other educational and cultural institutes, and between themselves. New methods were developed, piloted and evaluated, and all participating partners have taken steps to continue their knowledge exchange and practice of new methods. This new connection between formal and informal educational venues can in the future strengthen a Nordic platform in the development of new interdisciplinary methods and innovative approaches.

\subsection{ERMOND}

\subsubsection{Main objectives}

The aim of the ERMOND project (Ecosystem Resilience for Mitigation of Natural Disasters) was to facilitate new thinking and new solutions in preventing damage and loss of lives due to natural hazards in the Nordic countries. 
Figure 6: Flooding in the Mårdsele rapids in the Vindel River, northern Sweden

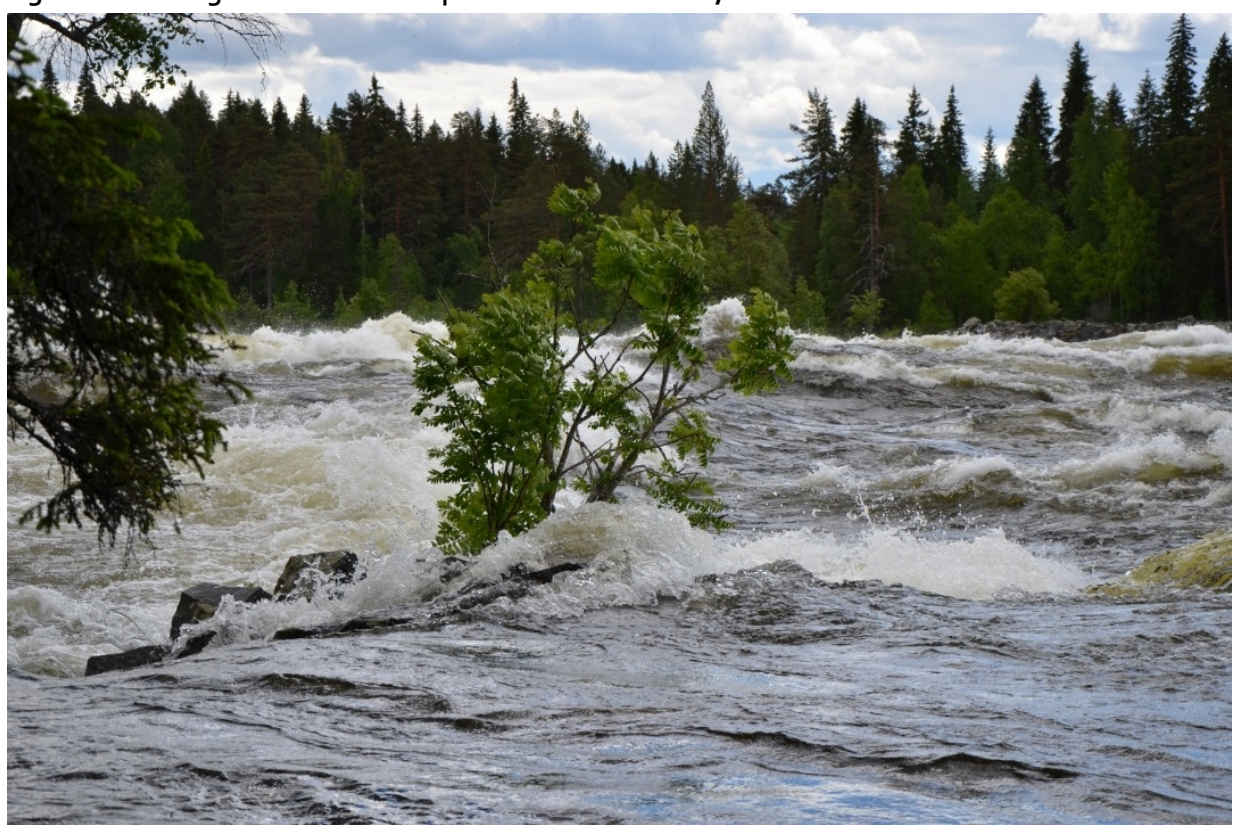

Source: Christer Nilsson.

\subsubsection{Background}

Many natural hazards threaten the Nordic countries, causing serious damage and losses of lives every year. Such hazards have primarily been met by warnings before disaster strikes, emergency relief after a disaster occurs, and hazard reduction measures such as levees to reduce the likelihood of a future disaster. There are many reasons to believe that strategic build-up of ecosystem resilience would better serve the aim of disaster risk reduction.

Natural ecosystems have an inherent ability to reduce the effects of natural disasters. By restoring natural ecosystems, ecological resilience can be increased and the effects of natural disasters reduced. Despite the international recognition of the role of ecosystems in disaster risk reduction, there is limited progress in applying such solutions in policy and practice. The need for such actions is increasing as human induced ecosystem degradation has resulted in a worldwide reduction in the capacity of ecosystems to provide protection against natural disasters.

Presently, there exist few Nordic projects directly aimed at restoring ecosystems for ecological disaster risk reduction (Eco-DRR). Therefore, enhanced ecosystem resilience is usually a side effect of ecosystem restoration planned for other purposes and thus may not entirely fulfil the objective of ecological disaster risk reduction. However, applying ecological solutions to minimise the impact of natural hazards will become increasingly important in the future as continuously growing populations and predicted climate change impacts are likely to increase the costs of natural hazards to the Nordic societies. 
Ecological solutions are not the only answer; often a combination of "green" ecological solutions and "grey" engineering solutions may be needed. However, the use of ecological approaches should be explored as a first choice and encouraged in order to reduce society's vulnerability to natural hazards. Preventative measures and green solutions may provide less expensive alternatives compared to using only grey solutions or the high cost of post-event reactions. Ecological approaches also provide a wide array of other benefits for ecosystems, local economies, the social fabric and the broader environment.

One way to facilitate ecological solutions is to recognise that there is a synergy between Eco-DRR and the other benefits of restoring ecosystems. Investment in ecosystem-based DRR and green solutions can thus provide many benefits for innovative risk management approaches, adapting to climate change-related risks, maintaining sustainable livelihoods and fostering green growth as well as ecological benefits of carbon sequestration, biodiversity, environmental protection, and natural resource management. Information gaps need to be overcome in order to support decision making in Eco-DRR governance, exploring possible solutions, their costeffectiveness and ecological benefits that are often difficult to quantify in monetary terms. The multiple benefits of ecosystem approaches should be captured in the equation as having positive spin-off impacts whereas grey solutions typically only fulfil single functions, especially since financial resources are often limited. Therefore, although the need for restoration of certain ecosystem services, such as ecosystem resilience, is of high importance this must not result in a single target focus at the cost of broader and more holistic aims. To accomplish this, projects aiming at enhancing Eco-DRR must be planned in a way that also supports broader aims of restoration, such as protection and enhancement of biodiversity.

Facilitation of the use of ecological solutions requires the involvement of different sectors: government, local community, scientific and engineering guidance and practice, and stakeholders in order to provide acceptable win-win solutions. A balance needs to be formed concerning resilience towards different goals, approaches and competing interests. Development of implementable long-term strategies for reducing future losses and aiding recovery from natural disasters needs to be included as a part of sustainable land use and spatial planning.

Opportunities to explore this further are needed to promote successful implementation of ecological approaches for disaster risk reduction at local, regional and national level, and across the Nordic region. 


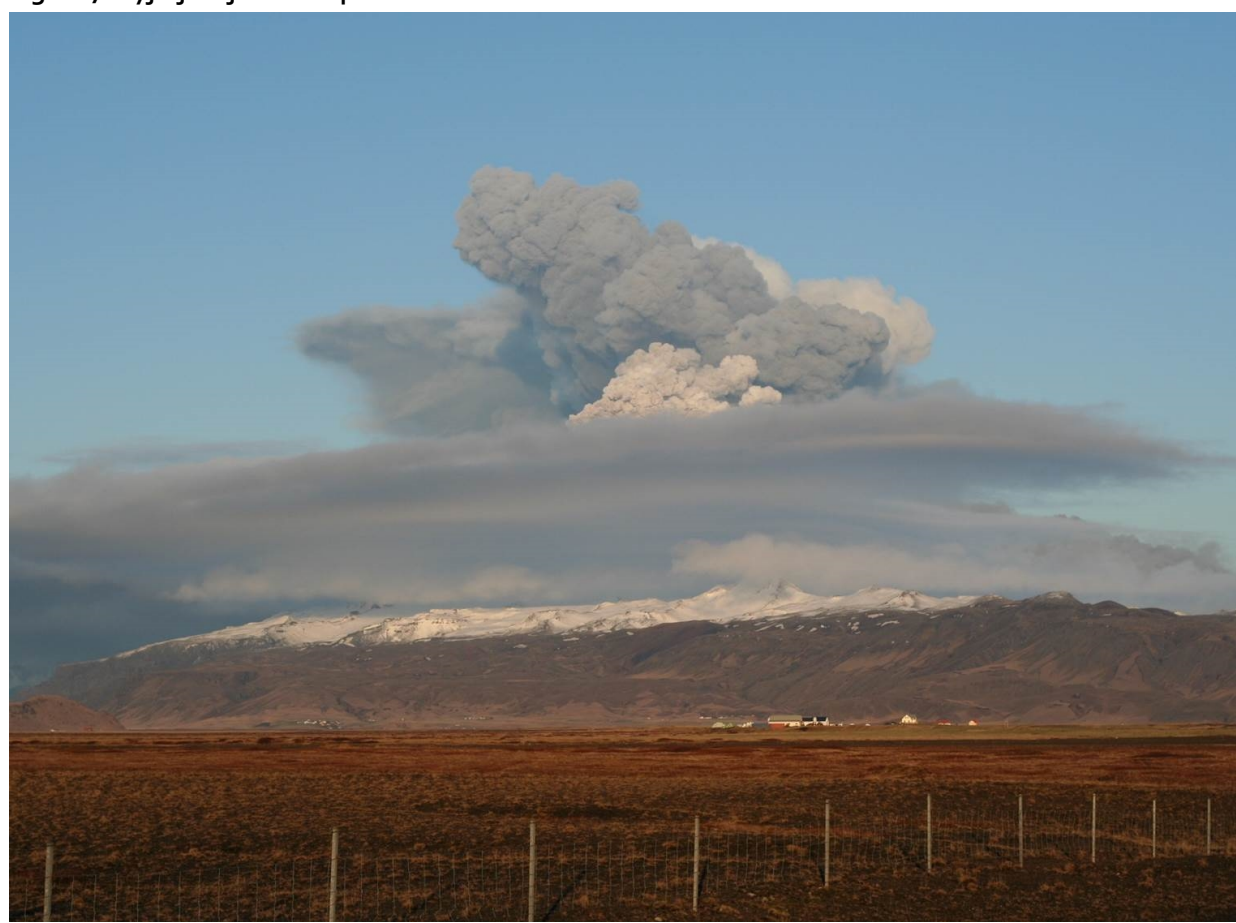

Source: Guðmundur Halldórsson.

\subsubsection{Implementation and expected outcomes}

The ERMOND project was divided into five work packages.

1. Creation of a network of Nordic institutions of organisations working with natural hazards, ecological restoration, and nature conservation

In total fifteen institutions participated in the network. In addition, four institutions were part of a wider network receiving information on project activities. Project partners came from Denmark, Finland, Iceland, Norway, Sweden, and the Faroe Islands. Network activities were organised in annual project meetings.

2. Compilation of an overview of natural disasters in the Nordic region and potential use of ecological restoration to reduce the effects of such disasters

This work was initiated in a workshop held in Iceland in May 2015. Information on natural hazards in the Nordic countries was gathered from partners working with natural hazards. This was matched with information on ecosystem conditions in the region, gathered by partners working with ecological restoration and nature conservation. This information was consolidated in a workshop in Copenhagen in November 2016. The results will be published in a scientific article. 
3. Case studies on the feasibility of strategic build-up of ecosystem resilience towards three specific hazards: floods, storms and volcanic activity

All case studies were further specified during the work process. Case studies were led by different partners. This research was conducted through desk studies, combined with workshops to consolidate the information. The results from each case study will be published in scientific articles.

4. Integration of Nordic policy on restoration of degraded ecosystems with restoration of ecological resilience

There is a growing concern that restoration of specific ecosystem services may occur at the cost of holistic goals of ecological restoration. The ERMOND network conducted a specific study of such potential conflicts and how to avoid them. This was conducted as a desk study, led by one of the project partner, and combined with workshops to consolidate the information. The results will be published in scientific articles.

5. Recommendations of actions to facilitate build-up of ecosystem resilience in the Nordic region

The results from the ERMOND project and recommendations for policy and action will be consolidated in a TemaNord report and a policy brief published by the Nordic Council of Ministers.

The project was funded by the Nordic Council of Ministers through: (a) the NordBio program, (b) the Nordic Committee of Senior Officials for Environmental Affairs (EK$M)$, and (c) the Terrestrial Ecosystem Group (TEG).

\subsection{Innovation in the Nordic Bioeconomy}

\subsubsection{Main objectives}

The overall objective of the project Innovation in the Nordic Bioeconomy was to have direct economic impacts through innovation and value creation in the Nordic bioeconomy and thereby strengthen regional and economic growth. Focus was placed on executing pilot projects covering one or more category: product development, sustainable food production, and increased production of biomass.

Different approaches to innovation were applied in the project. Product development projects were carried out using local resources, bioeconomy consortiums were founded, and cooperation established on identifying innovation opportunities within the bioeconomy.

\subsubsection{Product development projects}

A number of product development projects were carried out with local producers in the West Nordic region (Faroe Islands, Greenland, and Iceland), focusing on innovation and increased sustainability of food production, increasing the efficiency of bioresource 
utilisation and creating new value from side streams of food processing. In those projects the approach involved minimal administration, and focused on the maximum contribution to the execution of projects. The application process was simple and open to the public. The projects were selected based on predefined criteria and support was given in the form of "innovation vouchers" administered by the specialist assisting each entrepreneur. An "innovation voucher" gave the entrepreneur right to receive expert assistance worth a certain amount to develop an innovation project. The assistance was provided by appointed partners that had been publicly funded to participate. Project partners in the development projects were Matís (Iceland), Invili Culinary School (Greenland) and Inova (Faroe Islands).

The first phase of the product development projects took place in 2014. A call for applications for support for innovation projects was published in Iceland, Greenland and the Faroe Islands. 78 applications were submitted in the three countries, 30 projects were selected for support, resulting in 26 finalised projects. Products from this first phase of the project were presented and tasted at the Nordtic conference in Selfoss Iceland (25 June 2014).

The second phase of the product development projects started in 2015 and was finalised in 2016. A call for applications was again published in Iceland, Greenland and the Faroe Islands. This time 74 applications were submitted in the three countries, and 45 projects selected for support, resulting again in 26 projects being finalised with products.

Figure 8: Product presentation at "Minding the Future"

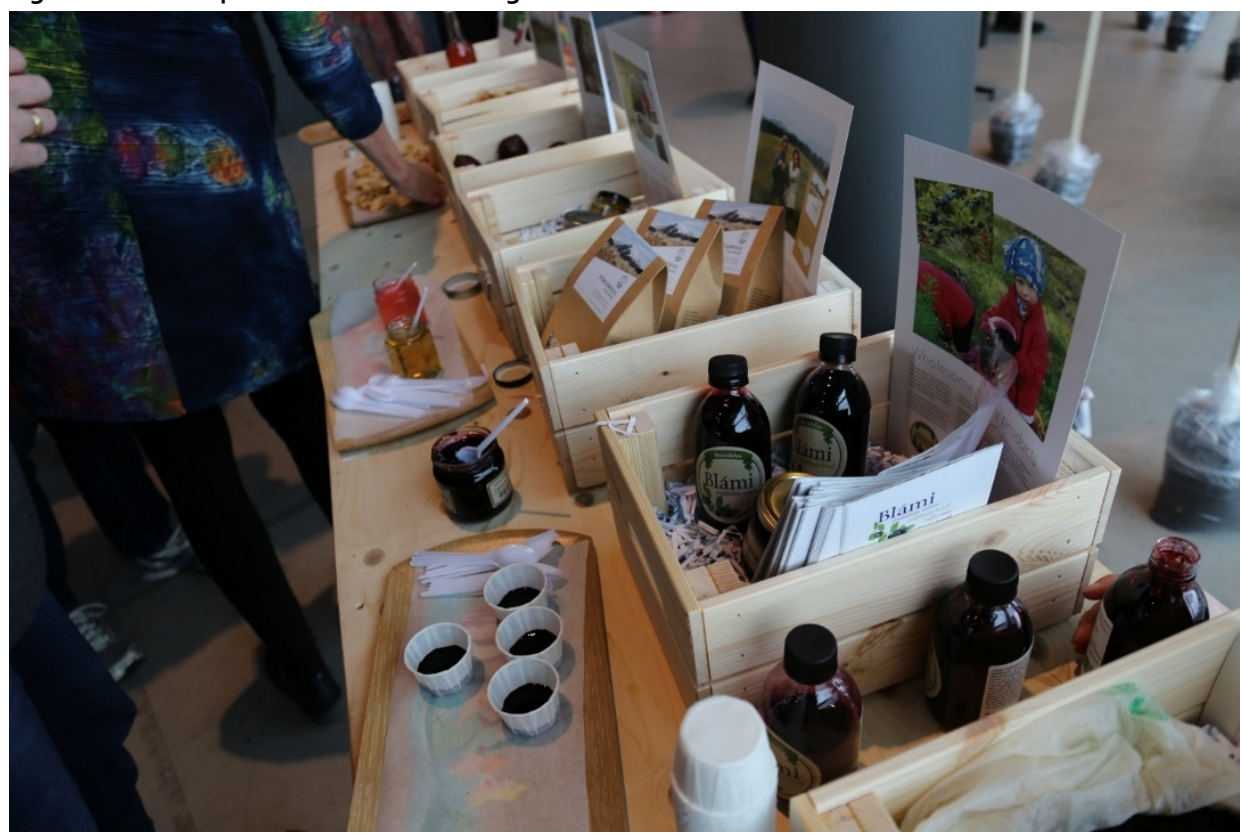

Source: Matís/Sigurður H. Guðjónsson. 
Products from the second phase, along with several products from the first phase were presented and tasted at the NordBio final conference in Reykjavík on 5-6 October 2016, "Minding the Future - Bioeconomy in a Changing Nordic Reality". Posters were made for all the products, available for further marketing of the products. In total, 152 applications were turned in, of which 75 were selected for participation. 52 projects were finalised with products.

This method of using "innovation vouchers" proved effective, resulting in the majority of the funding going directly into solving issues in the projects themselves.

\subsubsection{Bioeconomy consortiums}

Bioeconomy consortiums throughout the Nordic countries were founded to share knowledge and work on common goals connecting academia, research and industry together for the further development and implementation of the bioeconomy. The project was planned in collaboration with Nordregio on the basis of their prior in-depth regional study of the Nordic bioeconomy in 2014. A network was established with key players from Forssa region in Finland and Örnsköldsvik region in Sweden for planning innovative research in support of bio-industries in these regions and subsequent strengthening of the regional bioeconomy, specifically targeting Nordic and European $\mathrm{H}_{2020}$ funds for collaborative projects in the field of biorefineries. Participating countries are Sweden: SP-Processum \& Lund University; Norway: SINTEF Materials and Iceland Matís; Denmark: DTU, the Center of Biosustainability; and Finland: Häme University of Applied Sciences, Forssa and Natural Resources Institute Finland Forssa.

Three main subjects were selected:

- The Wood biorefinery with the goal of (1) increasing fermentability of wood hydrolysates; (2) production of high added value chemicals from wood (enzymatic, chemical, microbial), and (3) production of feed for aquaculture from wood-using microbes.

- Agricultural side stream and rest raw materials as feedstock biomass for biorefineries. with two main goals: (1) production of added value products from agricultural waste, and (2) identification of products, thresholds, challenges and subsequently innovative bioconversion tools and processes.

- Feed production with two main goals: (1) converting organic "waste" into valuable products, and (2) producing protein-rich feed for salmonids developed from waste from agriculture and fish processing with black soldier fly.

Activities in the period include:

- Network meetings for strategy planning and subject developments were held in Reykjavík, Forssa, Trondheim, and Örnsköldsvik.

- A test project for utilising side streams from wood biorefineries for production of single cell protein enriched in biocolorants (carotenoids) for fish feed using a novel 
thermophilic bacterium was carried out by Matís, Lund University, SP-Processum and Domsjö in Örnsköldsvik. The project was reported in Processums, newsletter, 15 December 2016.

- Two Finnish projects involving research groups in Forssa were started in the period with Matís as a foreign partner: "Value added compounds from food industry by-products" and "Utilization of algal components and biomass as food, feed and fuel".

- Two Nordic project applications, "Wood4Chem" and "Advancing bioeconomy by practical application of research results in education and enterprises" and two EUH2O2O applications, Thermorefine and Microbricks, have been submitted by the consortia to the European Union in the period.

\subsubsection{Cooperation on identifying innovation opportunities}

Cooperation with the Icelandic Environmental Agency was established on forming and initiating a West Nordic waste project. The aim was to use the results of the project to identify innovation opportunities that could be further developed. This cooperation has resulted in a project supported by the Nordic Council of Ministers, Working group for Sustainable Consumption and Production (HKP), focusing on utilisation of side streams from the fishing industry in Iceland, Greenland and the Faroe Islands.

Cooperation with the "Biorefinery testcenter opportunity mapping" project was also established. The project was led by Dr. Lene Lange with the aim of identifying possible innovation projects in the field of biorefineries.

\subsubsection{Conclusion}

A significant need exists for innovation support in the bioeconomy. This is evident from the responses that the project received and the number of applications, as well as from incoming requests regarding support after the project ended. A further conclusion is that the simple approach of "innovation vouchers" can be an effective way to stimulate innovation and transfer of knowledge and technology, increasing the value of bioresources, especially side streams from traditional forms of production. On the other hand, when it comes to highly scientific research projects within the bioeconomy, more network building, preparation and careful selection of projects to take forward is needed, and capacity support in the initial stage leading up to international research projects is important. 


\subsection{Nordic Marina}

\subsubsection{Main objectives}

The overall goal of the project Nordic Marina is to reduce emissions and increase the use of alternative fuels in the marine sector. To do so, the project aims to create a network involving key players in all of the Nordic countries. This will help to identify policy and roadmap recommendations for Nordic policy and decision makers on how to increase the use of alternative fuels and reduce emissions from marine applications.

It is important to increase efficiency and reduce waste in the fragile environment of the North Atlantic. The recommendations formed by the project team shall include goals for 2025 and longer term objectives. They should suggest actions, national and Nordic programs, international cooperation, infrastructure and alternative fuel resources among others.

\subsubsection{Background}

Over the last few years all of the Nordic countries have been promoting increased use of environmentally friendly fuels, mainly focusing on land transport. Norway, for example, is the world leader in using battery electric cars, and other Nordic nations have promoted increased use of bio-fuels, hydrogen and electricity directly. All of the Nordic nations have set forward policy goals regarding emission reductions from transport and there is a good cooperation between industries in that field, as well as established networks.

This level of cooperation and shared policy goals currently does not exist for marine applications. Oil consumption can be very high. In some cases, more than $1 / 2$ kilogram of oil is burned to catch 1 kilogram of fish. Technical developments in land transport have occurred in the last few years but there are many challenges in adopting those developments for marine applications and in some cases alternative solutions need to be found. The Nordic countries have taken steps towards increasing the use of domestic resources to substitute for fossil fuels. Strides have been made to increase the use of bio-fuels and renewable electricity. The marine sector can be an ideal platform for utilisation of such resources. However, little progress has been made. 
Figure 9: Oil consumption in marine applications can be very high. Slide from a presentation at the "Arctic Know-How as Strength" seminar in Helsinki, Finland, 18-19 March 2015

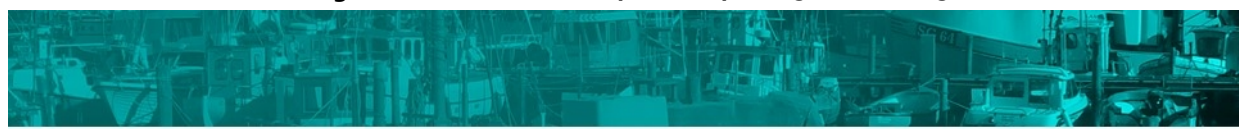

\section{Oil consumption}

- The fisheries and marine transport industries of the Nordic countries consume

- 5 million tonnes of oil each year

- which corresponds to 100.000 barrels per day

- Fish is costly in terms of oil: $1 / 2 \mathrm{~kg}$ of oil per $\mathrm{kg}$ fish

- Remember that the Arctic and the North Atlantic are hosts to important and vulnerable ecosystems.

- The world expects great increases in shipping and transport in the Arctic regions in the coming years and decades.
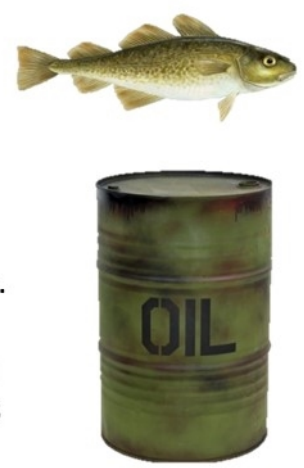

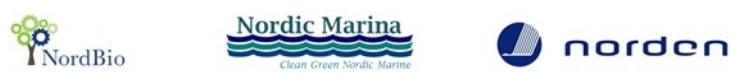

Source: Anna Margrét Kornelíusdóttir / Icelandic New Energy.

Norway has had tremendous success in increasing the share of zero emission vehicles in land transport since implementing extensive economic incentives and tax concessions. This is evident when summarizing the advances made in each of the five Nordic countries with regards to greening land transport and marine transport, as shown in the table below. Government policy and actions in favour of low and zero emission technology in Norway and Iceland and, to a lesser extent, in Denmark, have clearly established a presence of alternative fuel vehicles.

However, actions and targets for marine transport are indeed lagging, with correspondingly mediocre results in all five countries. Norway is, again, the exception. In fact, a Nordic Marina workshop in Bergen in 2016 revealed that only Norway has a clear policy when it comes to definitive targets for change within the marine sector. This is further reflected in the number of projects and activities taking place in the Nordic countries, where Norwegian initiatives are leading. Nonetheless, each nation has made notable efforts in that direction by, for example, supporting specific projects and providing some infrastructure. This is certainly an issue for decision makers to address and take into account, given the ambitious climate goals set for 2020, 2025 and 2030. 
Figure 10: Overview of Nordic government policy and actions for the promotion of alternative fuels in land and marine transport

\begin{tabular}{|c|c|c|c|c|c|c|c|c|}
\hline & $\begin{array}{l}\text { C02 tax } \\
\text { incentive }\end{array}$ & $\begin{array}{c}\text { VAT } \\
\text { incentive }\end{array}$ & $\begin{array}{l}\text { Provision of } \\
\text { infrastructure }\end{array}$ & Procurement & $\begin{array}{c}\text { Government } \\
\text { policy }\end{array}$ & $\begin{array}{c}\mathrm{RD} / \mathrm{D} \\
\text { funding }\end{array}$ & $\begin{array}{c}\text { Adoption } \\
\text { international } \\
\text { standards }\end{array}$ & $\begin{array}{c}\mathrm{CO2} \\
\text { specific } \\
\text { targets }\end{array}$ \\
\hline $\begin{array}{l}\text { Marine transport } \\
\text { Land transport }\end{array}$ & $\begin{array}{l}* \\
+ \\
+\end{array}$ & $\begin{array}{l}. . \\
\cdots\end{array}$ & $\begin{array}{l}\cdots \\
+ \\
\end{array}$ & $\begin{array}{l}\cdots \\
+ \\
+\end{array}$ & $\begin{array}{l}\cdots \\
++\end{array}$ & $\begin{array}{c}+1 \\
+\end{array}$ & $\begin{array}{l}++ \\
++\end{array}$ & $\begin{array}{l}* \\
++ \\
+\end{array}$ \\
\hline \begin{tabular}{|l|} 
Marine transport \\
Land transport \\
\end{tabular} & $\begin{array}{l}\cdots \\
\cdots\end{array}$ & $\begin{array}{l}\cdots \\
\cdots\end{array}$ & $\begin{array}{l}. . \\
+1 . \\
\end{array}$ & $\begin{array}{l}\cdots \\
\cdots\end{array}$ & $\begin{array}{l}. . \\
+1 . \\
\end{array}$ & $\begin{array}{l}+ \\
+ \\
\end{array}$ & $\begin{array}{l}++ \\
++ \\
\end{array}$ & $\begin{array}{l}+1 . \\
+4 \\
\end{array}$ \\
\hline $\begin{array}{l}\text { Marine transport } \\
\text { Land transport }\end{array}$ & $\begin{array}{l}\cdots \\
+4 \\
\end{array}$ & $\begin{array}{l}\cdots \\
+4 \\
\end{array}$ & $\begin{array}{r}. . \\
+1 . \\
\end{array}$ & $\cdots$ & $\begin{array}{l}\cdots \\
+4 \\
\end{array}$ & $\because$ & $\begin{array}{l}\cdots \\
+4 \\
\end{array}$ & $\begin{array}{l}* \\
+ \\
\end{array}$ \\
\hline $\begin{array}{l}\text { Marine transport } \\
\text { Land transport } \\
\end{array}$ & $\begin{array}{l}\cdots \\
+4 \\
\end{array}$ & $\begin{array}{l}\cdots \\
+4 \\
\end{array}$ & $\begin{array}{l}+1 . \\
+4 \\
\end{array}$ & $\begin{array}{l}+ \\
+ \\
\end{array}$ & $\begin{array}{c}+ \\
+4 \\
\end{array}$ & $\begin{array}{l}++ \\
++ \\
\end{array}$ & $\begin{array}{l}++ \\
+4 \\
\end{array}$ & $\begin{array}{r}+ \\
+4 \\
\end{array}$ \\
\hline $\begin{array}{l}\text { Marine transport } \\
\text { Land transport }\end{array}$ & $\begin{array}{l}\cdots \\
\cdots\end{array}$ & $\begin{array}{l}\cdots \\
\cdots\end{array}$ & $\begin{array}{l}. . \\
+1 .\end{array}$ & $\begin{array}{l}. . \\
+1 .\end{array}$ & $\begin{array}{l}* \\
+\end{array}$ & $\begin{array}{l}+ \\
+\end{array}$ & $\begin{array}{l}++ \\
+4\end{array}$ & $\begin{array}{l}+1 . \\
++\end{array}$ \\
\hline
\end{tabular}

\subsubsection{Implementation}

During 2015 and 2016, Nordic Marina held seven workshops, two of which were specifically aimed at bringing together public and private stakeholders and gathering information on opportunities in the green marine fuel sector. Topics for discussion were decided upon beforehand and participants were divided into groups, each addressing one topic with the guidance of a facilitator, who was also responsible for taking minutes from the group's deliberation. The outcome of each workshop was an overview of barriers to new technology adoption, opportunities in marine industries and distinct means via which the barriers may be overcome. The partners involved in the organisation of Nordic Marina workshops and think tanks include but are not limited to: NCE Maritime CleanTech (NO), Tekes (FI), Danish Maritime (DK), Swedish Maritime Administration (SE), Icelandic Transport Authority (IS), Wärtsilä (SE), National Energy Authority of Iceland (IS) and, acting as Nordic Marina's Secretariat, Icelandic New Energy (IS).

\subsubsection{Main outcomes}

Following its launch, Nordic Marina successfully created a common Nordic platform enabling stakeholders to form a network, where they could exchange ideas and discuss potential projects. This network has since then proven valuable for the purposes of creating consortia for green marine projects and related grant applications. Several projects have been launched during Nordic Marina's working period, including "Electrification of harbours", whose goal is to map available electric infrastructure and demand thereof in Finnish, Icelandic and Norwegian ports. Furthermore, Nordic Marina hosted two Nordic conferences under the title "Making Marine Applications Greener", one in Gothenburg and the other in Reykjavík. These brought together key stakeholders from the Nordic countries and other European countries for updates on leading green projects in the maritime industry and discussion 
on the possibilities for eliminating barriers to the further development of alternative marine fuels and deliver emissions reductions.

Marking the conclusion of its formal working period, Nordic Marina set out to compile the knowledge and feedback obtained at its workshops to produce a Nordic Roadmap for technological development and further movement toward greening the Nordic maritime sector. Nordic Marina's white paper is the product of its networking efforts and information gathering among Nordic stakeholders. It deals not only with the barriers to a greener marine industry but also, and more importantly, the great opportunities that emerge with the adoption and promotion of alternative fuels. The white paper will be made available at www.nordicmarina.com in early 2017. In addition to the white paper, the project hosted a conference to disseminate key findings. It is expected that the Nordic Marina network can continue after the lifetime of the project, and become to some extent self-sufficient.

\subsection{WoodBio: Wood biomass in the Nordic Bioeconomy}

\subsubsection{Main objectives}

The WoodBio project aimed to highlight the role of forestry in the Nordic bioeconomy with emphasis on wood biomass as raw materials. The main objectives of the project were:

- to map the present state of the utilisation of wood biomass in the Nordic countries

- to estimate available land area for afforestation in the Nordic countries

- to study the cultivation of wood biomass by applying dedicated forest plantations with fast growing tree species with short rotation periods

- to analyse the developing industries (Innovation) utilising wood biomass in the Nordic countries

- to study the supply and demands expected to be required for new developing industries in the future $(2030,2050)$.

\subsubsection{Background}

Wood is considered to be one of the most common raw materials used by the Nordic countries. Wood is a primary material for construction, furnishings, printing, packaging and energy production. It is considered more environmentally friendly than competing materials such as plastic, steel, concrete and glass, especially when the entire product life cycle is taken into account. The use of wood products can also have a substitution effect on carbon emissions, since the manufacture of wood products normally consumes less energy from fossil fuels than the production of products from competing materials. The Nordic forests therefore contribute to economic, social and environmental aspects. 
Hence, forest products play an important role for the realisation of the bioeconomy concept; they are renewable, ecologically friendly and can be recycled.

\subsubsection{Implementation}

The project was conducted on a Nordic level; all the five Nordic countries participated in the project. The funding was disseminated between the different Nordic partners and they worked on different research questions related to the main objectives of the project. The most relevant Nordic researchers or institutes were selected as partners for this project. The institutes involved were Iceland Forest Service (IFR) (IS), Natural Resources Institute Finland (LUKE) (FI), Swedish University of Agricultural Sciences (SLU) (SE), SweTree Technologies (SE), University of Copenhagen (KU) (DK), SINTEF (NO) and Energigården (NO). Workshops and meetings were held annually and an open final conference with guest lectures was held in connection with the NordBio final conference in October 2016.

\section{Danish contribution}

Effects of seasonal cutting on moisture content of poplar timber and biomass (Palle Madsen, KU).

\section{Finnish contribution}

Future supply and demands for forest biomass required for the developing industries, including the industries producing advanced biofuels (Maarit Kallio, LUKE). Factors affecting coppicing and biomass production of hybrid aspen and native birch (Jyrki Hytönen, LUKE).

\section{Norwegian contribution}

Mapping the developing industries (Innovation) utilising wood biomass in the Nordic countries (Judit Sandquist, SINTEF). Study of the importance of the pellet market in the Nordic countries (Hrefna Jóhannesdóttir, Energigården).

\section{Swedish contribution}

Hardiness zones for Nordic countries based on growth rhythm- and phenology of poplar clones bred for higher latitudes (Almir Karacic, SLU).

Icelandic contribution

Selection of most suitable poplar clones for Icelandic conditions, establishment of collection of selected plus clones and testing of rust resistance (Halldór Sverrisson, IFR). Research on plantation yield. Optimising the stand density, sites quality study, establishing yield models (Porbergur $\mathrm{H}$. Jónsson, IFR). Poplar coppice regeneration. Study on the effects of harvesting season on coppice regeneration, survival, competition and yield (Porbergur $\mathrm{H}$. Jónsson, IFR). The carbon balance of poplar plantations on drained wetlands (funding independent of the WoodBio project). 


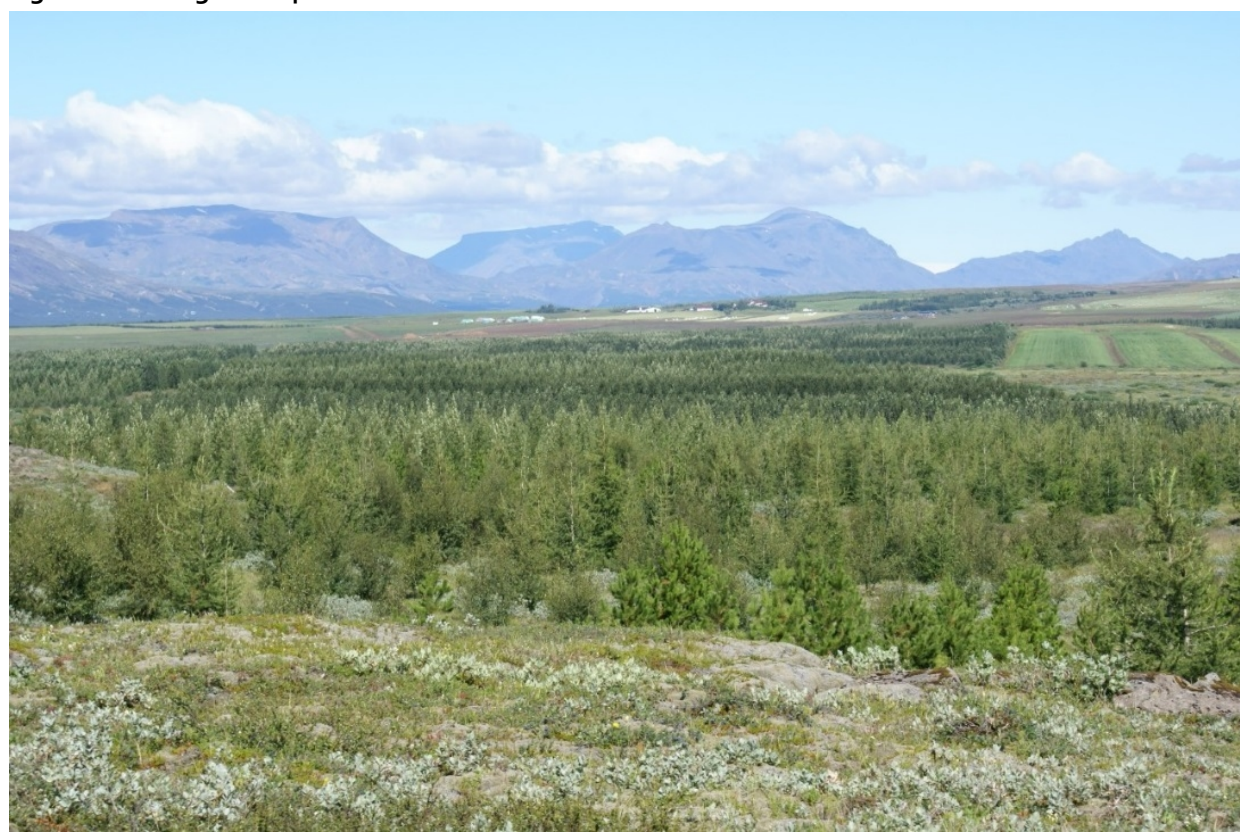

Source: Halldór Sverrisson.

\subsubsection{Main conclusions}

Available land for wood biomass production

In Denmark it became a political goal in 1994 to obtain $20-25 \%$ forest land within three generations (100 years). Based on this goal, 250,000-470,000 ha are required for afforestation in Denmark.

In Iceland, the political goal from the year 2000 was to afforest $5 \%$ of the lowland area, 210,000 ha (area below $400 \mathrm{~m}$ asl) during the coming decades. Close to 50.000 ha (1.5\%) had been afforested in 2015 . Therefore, 160.000 ha are required for afforestation during the coming decades. (Björn Traustason et al. 2009). Good arable cropland in Iceland (below 100m asl) is estimated to be 600,000 ha, and only circa 120,000 ha are used as cropland today (2016). A considerable land area is therefore available for afforestation in Iceland. Drained peatlands in Iceland, presently not used for farming, have a great potential as sites for dedicated forest plantations using fast growing tree species like Populus sp.

Land areas for afforestation are limited in Norway, Finland and Sweden due to their already large share of forested land. In Norway, 175,000 ha of coastal heathland may potentially be afforested (Granhus et al. 2012). Due to restrictions, it is not possible to convert open and abandoned cropland to forest in Norway.

The total area of uncultivated arable land available for afforestation in Finland was estimated to be around 276,000 ha in 2011 (Ministry of Agriculture and Forestry in Finland 2012). 
In Sweden, areas not actively used and available for afforestation are estimated to be 300,000-500,000 ha (Larsson et al. 2009). In Sweden the use of Salix sp. and Populus sp. does not change the land use class to forest land if cultivated as short rotation forestry for energy purposes, with rotations of less than 10 and 20 years respectively.

From the estimates above it can be concluded that 1.1-1.6 million hectares of available land area exist for afforestation across the five Nordic countries as a whole.

The wood biomass resources in The Nordic countries

Ambitious goals of increasing forest production by using better forest management practices exist in most of the Nordic countries. Sustainable forest management is an overall objective in the Nordic countries. Ongoing tree breeding programs in WoodBio have resulted in more resistant and highly productive trees (mainly Poplars and Aspen) adapted for Nordic conditions. These trees enable the creation of dedicated forest plantations for wood biomass production that can replace fossil carbon products and enhance the Nordic bioeconomy.

The Nordic pellet market is small but increasing. Pellets often replace oil and coal for heating. Despite large forest reserves and relatively high level of wood pellets production in the Nordic countries, the import of pellets is needed to meet bioenergy goals. This is particularly relevant to Denmark, where ambitious aims are in place to replace coal and heating oil with pellets for energy production. Therefore, the pellet production market should have the potential to grow and further strengthen the Nordic bioeconomy.

Figure 12: Regeneration of Populus two years after clearcutting. From an experimental forest in South Iceland

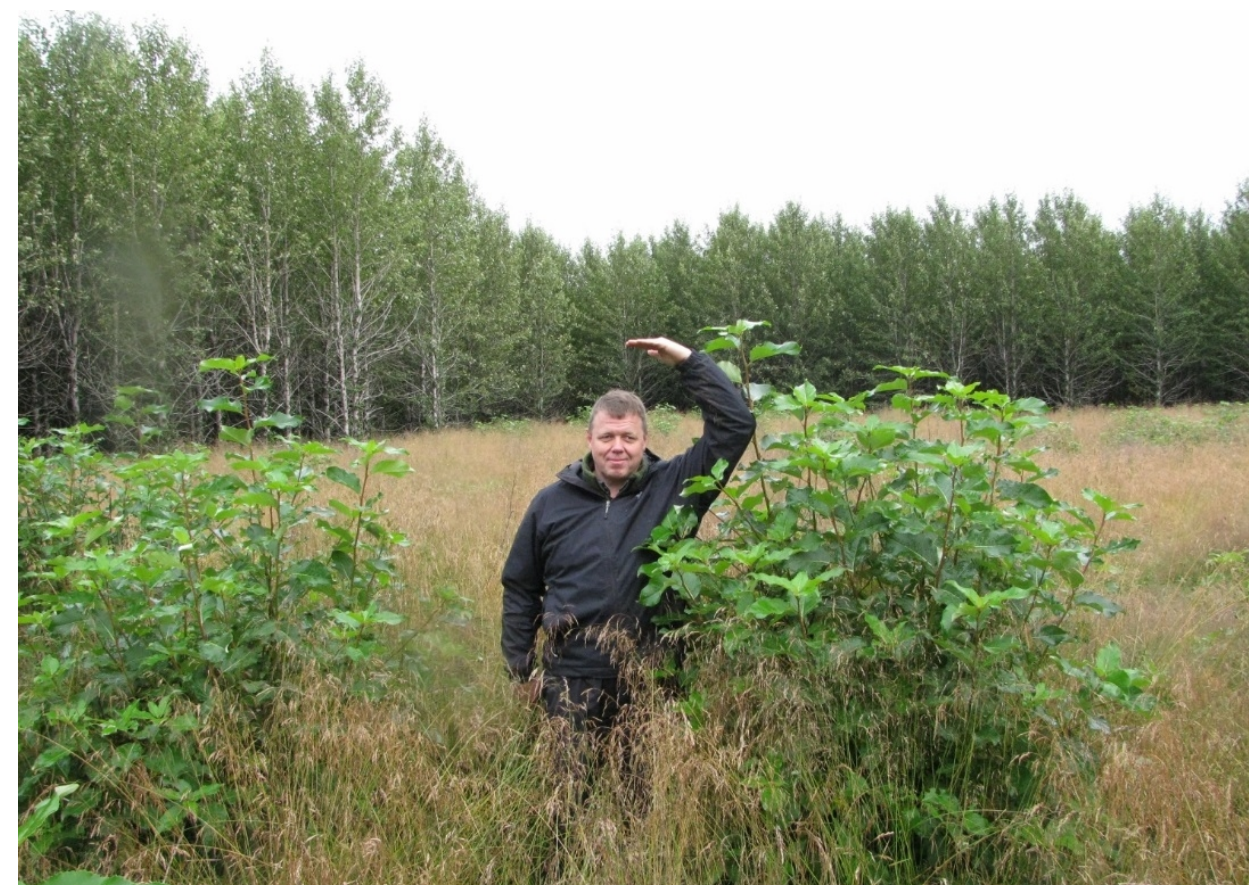

Source: Ólafur Eggertsson. 
The future use of wood biomass in Nordic bioeconomy

The pulp and paper industry in the Nordic countries has been facing challenging times forcing them to look for new ways of utilising wood biomass applications. A significant market increase is expected for biofuels for transport, and the aviation industry is very interested in biofuels, as that industry has few other alternatives to mitigate GHG emissions. Biomass is a finite resource, and when sustainably produced it contains the only renewable carbon source. Hence, the application possibilities are almost unlimited. Price, market and politics will determine the future uses, and with changing markets, the stakeholders will need to be prepared for rapid changes and adjustments in the products. High quality biomass is expected to be used in the production of biomaterials, while lower quality biomass will be processed in biorefineries to yield petroleum substitutes as well as energy. In the near future, biochemicals, biofuels (especially for aviation) and materials (especially for construction) seem to be the most favoured products from biomass resources, while biomass and waste for domestic and district heating purposes is expected to maintain its market share.

Can sustainably produced wood biomass meet the energy demands of future industries?:

- Before 2030: Demand-supply relationship is still rather balanced. Wood is important for energy, yet growth is focused on other renewables. Forest chips are the most important source for modern wood bioenergy. In the forest industry, the increase of round wood use can be satisfied by intensified use (more cutting) of today's Nordic forest resources.

- By 2050: On a global level it is estimated that of all the biomass resources that are currently considered being sustainably available, $80-90 \%$ can be used. New wood supplies are needed, including more dedicated plantations using fast growing tree species. Modernisation of the use of traditional wood fuel is also necessary. This will be fundamentally important in order to strengthen the industry with wood biomass from sustainable forest resources.

The future of the WoodBio project will be in the hands of the project coordinator and the different project partners. Most of the sub-projects established with direct funding from the NordBio program via the WoodBio project will continue in the coming years, however probably more on a national level than on a Nordic level. 



\section{Additional projects}

In addition to the five main projects, which have been described in the previous sections, a number of other projects and initiatives have been carried out under the umbrella of the NordBio program. The following sections include information about four of these projects.

\subsection{Sustainable Nordic Protein Production}

\subsubsection{Background and main objectives}

The aim of the project was to map plant protein supply for the Nordic food and feed industry, as well as to screen and describe the basic properties of available materials in gene banks to facilitate the use in breeding and pre-breeding in the Nordic countries. The focus was on agricultural traits that are important for Nordic breeders in their work to produce new well-adapted varieties for the region's current and future climate. The aim was also to establish a network with relevant stakeholders.

Protein crop production within the EU has declined dramatically in the last decade, leading to a dependence on imported protein. Protein crop production in the EU today occupies only $3 \%$ of arable land, whereas imported protein crops represent $80 \%$ of protein consumption.

Protein crops can be divided into 1) grain legumes/pulses, where peas, beans, fava beans, lentils, and soy beans are the most important crops that are used as human food and/or in feed for livestock and fish farming, and 2) fodder legumes, where red clover, white clover and lucerne/alfalfa are most important. In protein concentrates, soy bean is the most widely used ingredient. Sustainable Nordic protein production is possible, but requires increased research, pre-breeding and breeding activities, and cooperation between stakeholders, including farmers' associations, research institutes, and the breeding- and feed-industry. 


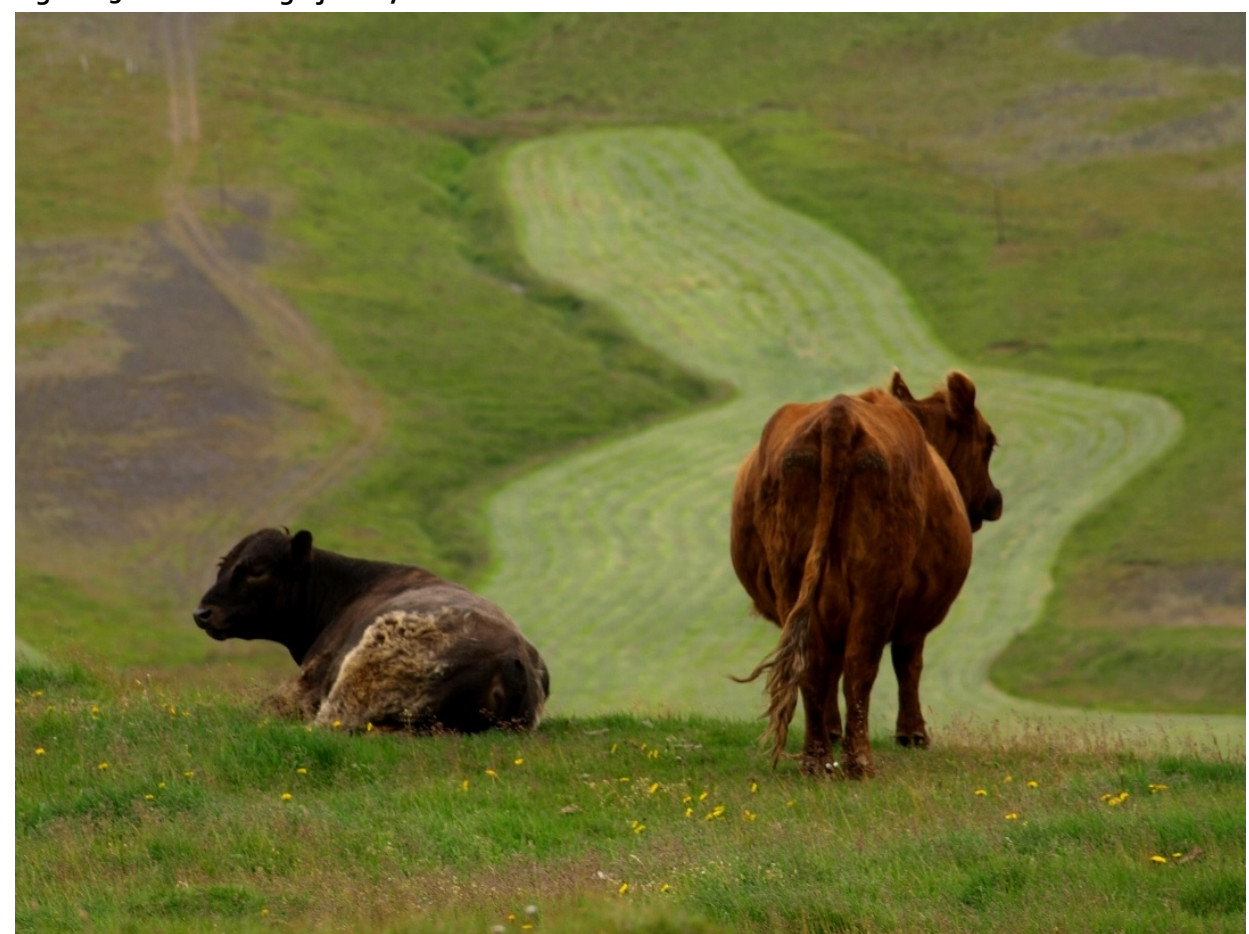

Source: Hugi Ólafsson.

\subsubsection{Implementation}

The project provided an overview and analysis of the current status and future prospects of protein crops and protein supply in the Nordic food and feed industry. The main topics covered by the project were discussed by experts and stakeholders at a workshop in Copenhagen on 20-21 November 2014. The workshop provided input into a report which was prepared by NordGen (Nordic Genetic Resources Center) in 2015. The project was combined with another project, "Baltic Sea Region/Nordic Sustainable Protein Production Initiative - mapping of regional potential", and the report covered both projects. (Poulsen \& Solberg 2015) The results were also published in the report Nordic Alternative Protein Potentials: Mapping of regional bioeconomy opportunities published by the Nordic Council of Ministers in 2016 (Lindberg et al. 2016).

The report, which was based on information gained at workshops (including the Copenhagen workshop), scientific literature and statistical sources, presented an overview of agricultural plants as bioresources for protein for the animal and fish feed industry. The purpose of the report was to promote more economically and environmentally sustainable agricultural production systems in the Baltic Sea region. It mapped the status and economy of protein crops cultivated in the countries, and on the basis of that it made recommendations concerning the political processes necessary to move forwards. The overview thus serves as an input to the political discussion on 
regional development and, more specifically, in relation to the development of regional bioeconomy strategies. (Poulsen \& Solberg 2015)

\subsubsection{Main outcomes}

The main recommendations of the report were the following.

Aiming at increased food security, we should work towards independency of massive imports of unsustainably produced soybean products. The application of grain legumes and forage legumes grown regionally offers a more environmentally sustainable production system of plant protein. For the Baltic Sea region, several priorities should be made:

- Policy: A higher degree of self-sufficiency in plant protein should be aimed for. The EU Common Agricultural Policy offers possibilities for giving incentives to diversify the crops and grow grain legumes. Measures for crop diversification, environmentally friendly agriculture, and organic agriculture support are suitable measures.

- Training: Conduct workshops and establish training to educate and motivate farmers and the agricultural extension services to reach the needed level of knowhow and expertise on protein plants.

- Collaboration and networking: Increase the collaboration and knowledge on cultivations of grain legumes, for example regarding improved agricultural practices and reintroduction of crop rotation. A good approach to do this would be to develop a regional strategic cooperation in the Baltic Sea region including stakeholders as farmers, plant breeders, livestock farmers, feed industry, food industry and retailers, including Canada/ Russia when it is relevant. Consider the establishment of a Nordic/Baltic protein centre of excellence or network (comparable to the Danube Soya Initiative and similar).

- Plant breeding: Motivate breeders, researchers and farmers to develop improved cultivars of grain legumes and emphasise the use of different species and a range of cultivars to enhance agrobiodiversity and thus food security. Long term public breeding programs or public private partnerships could be a good tool, as private breeding will not have the needed momentum to catch up the lost capacity during the low years. Independent of approach, long-term efforts are needed since plant breeding is a long-term effort. Important aims in the breeding work would be adaptation to the Nordic climate, including future climate changes and new pests, development of stable varieties well adapted to climate fluctuations and also work on reducing the nutrition inhibitors that are present in the feed proteins. The latter could be complemented with development of technological approaches. Facilitate the use of important genetic resources by establishing good characterisation and evaluation information on the germplasm stored in gene banks. 
- Innovation: Support development of bioprocessing facilities to exploit extraction of proteins from forage legumes and their utility in feeding monogastric animals and fish and for food purposes. (Poulsen \& Solberg 2015)

\subsection{Nordic bioresources: mapping sustainability criteria}

\subsubsection{Background and main objectives}

The bioresources of the Nordic countries directly contribute to the Nordic economies approximately $10 \%$ of GDP on average (Rönnlund et al. 2014). The Nordic Environmental Action Plan 2013-2018 recognised the contribution of bioresources to the growth of Nordic national economies and the need to ensure that a sensible balance is struck between their conservation and utilisation. Given the importance of bioresources for the Nordic economies it is important for continued and long-term regional prosperity that the bioresources of the region are used responsibly and their longevity is ensured through sustainable use. To be able to do so it is important for decision-makers to have an overview of both the volume and condition of all major bioresources in the Nordic countries as well as an understanding of state-of-the art management regimes with respect to sustainable utilisation.

In light of the above, the aim of this project was threefold: 1) to identify the main bioresources of the Nordic countries that contribute directly to Nordic economies, 2) to review the management regimes for the resources in question in each Nordic country, focusing on how allowable yield is determined, when applicable, and 3) to review availability of data on the condition of the Nordic bioresources such as data on catch and stock sizes. (Danielsen et al. 2016)

\subsubsection{Implementation}

Bioresources in the project are defined in accordance with the work of McCormick and Kautto (2013) as: "...an economy where the basic building blocks for materials, chemicals and energy are derived from renewable biological resources, such as plant and animal sources." Bioresources were grouped based on the economic sector to which they contributed, effectively applying a sector-based approach to the analysis. The analysed Nordic bioresources were divided into five sectors: agriculture, forestry, aquaculture, marine resources and game, including terrestrial and aquatic game species. Each resource was analysed with respect to 1 ) sectoral management structure with a focus on yield based or sustainability management criteria and 2) status of data that provides information on the condition of the resource in question. The countries included in the report were Denmark, Finland, Iceland, Norway, Sweden, Greenland, the Faroe Islands and the Åland Islands. 


\subsubsection{Main conclusions}

The results of the study were published in 2016 in the report "The Nordic Bioeconomy: sustainable utilization of bio-resources in the Nordic bio-economy" (Danielsen et al. 2016).

The results show that from the abundant marine resources of Norway and Iceland to the extensive forests of Sweden and Finland to the fertile soils of Denmark, Nordic bioresources have underpinned and continue to contribute to economic growth in these countries. Economically, as a proportion of GDP, the bioeconomy is largest in Iceland, but smallest in Norway. In Denmark, agriculture and the food industry are the dominant sectors of the bioeconomy but it appears that the country has potential to develop the bioeconomy further still, particularly in terms of the use of biomass from agriculture and forestry. In the Faroe Islands, fisheries remain by far the most critical sector to the bioeconomy. In Finland (including Åland), approximately 50\% of the bioeconomy is derived from forestry, while, in terms of employment, the agricultural industry is also very important. In accordance with the recommendations of the Finnish Bioeconomy Strategy, potential remains for increased use of wood for fuel, continued development of the biofuels industry, and production of non-food products from agriculture, such as textiles. The results depict that Iceland's bioeconomy is dominated by fisheries, followed by agricultural and aquaculture sectors. In Norway, the bioeconomy is dominated by the aquaculture and fishing industries, while other strong sectors include agriculture, and, to some extent, forestry. The Swedish bioeconomy is led by the forestry and agricultural sectors.

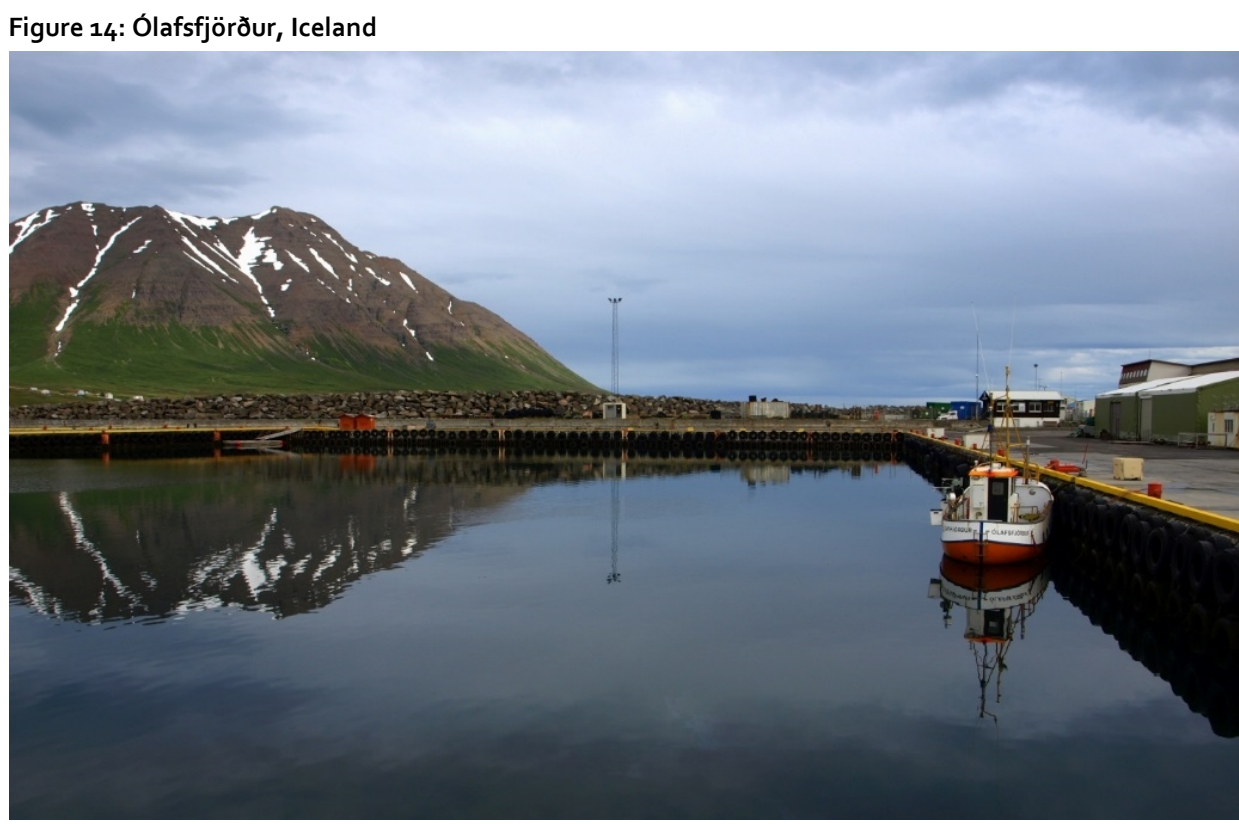

Source: Hugi Ólafsson. 
The results illustrate that management regimes for the various bioresources differ across the Nordic countries, but also, frequently, demonstrate common factors in legislative objectives, as expected. In accordance with the themes of a circular economy, increasing emphasis is placed on the waste products from one industry forming the valuable raw materials of another. The report illustrates that lessons could be learned between the Nordic countries. For example, the approach taken by Iceland in terms of ensuring sustainable use and thereby creating both productivity and value from its fisheries, particularly its demersal fishing and the nation's focus on full use of raw materials in its processing industry. In recognition that fish resources must be harnessed sustainably in order to continue to supply sufficient raw materials, Iceland has recognised the importance of strengthening fish stocks. Its system of Total Allowable Catch and Individual Transferable Quotas has strengthened fish stocks and efficiency in the fishing industry during the past two decades, while considerable efforts have been made to reduce waste generation and maximise processing yields. Equally the report illustrates cases where management plans have been slow to develop. In Greenland, for instance, there is no formal management strategy in place for marine resources. The development of a long-term, stable and attractive management plan for all Greenlandic fish stocks would help to ensure that stocks are maintained in accordance with maximum sustainable yield principles, while providing greater longterm certainty to potential investors in the industry.

Across the Nordic countries, a strong political focus can be detected on conservation and risk mitigation in the face of emergent challenges such as climate change, which is important as many of the bioresources common to the Nordic countries seem highly vulnerable to change, such as to ocean acidification. It is evident that a considerable untapped potential remains within the different sectors of the Nordic bio-economies but future growth will rely on the optimisation of value created from key bioresources and their sustainable utilisation.

\subsection{Innovation from organic waste}

\subsubsection{Background and main objectives}

Biodegradable waste is an underutilised resource. Substantial amounts of this potential resource go to waste with the associated environmental and financial costs. A trend in Europe has been to reduce waste disposal by keeping it within the economy, or a socalled circular economy, enabled through greater recycling and re-use.

The goal of the project was to enable and encourage green innovation, value creation, increased utilisation of natural resources, and a sustainable economy by providing information on potential resources through increased data collection, securing a supply of those resources, and showing where opportunities lie. To achieve this objective, an attempt was made at quantifying and mapping the formation of biodegradable waste in Iceland, the Faroe Islands, and Greenland for the purpose of facilitating the creation of markets for waste. 


\subsubsection{Implementation}

In order to quantify and map biodegradable waste in Greenland, the Faroe Islands and Iceland, waste disposal, potential sources of biodegradable waste, and waste management were studied in these three countries. Data was collected from the relevant agencies in each country. Emphasis was placed on by-products and waste from the fishing and meat industries since the largest sources of biodegradable waste were considered to lie within those industries.

\section{Greenland}

Data on biodegradable waste is not collected in Greenland, which made the analysis difficult. However, it was possible to draw certain conclusions based on other available data. The majority of waste generated in Greenland is incinerated since conditions are not suitable for landfill. The main sources of biodegradable waste, and thus the main opportunities for increased utilisation, were determined to lie within the meat and fishing industries.

The Faroe Islands

Limited data exist on biodegradable waste in the Faroe Islands. Nevertheless, it was possible to draw certain conclusions from the collected data. The main sources of biodegradable waste are household waste, biodegradable waste at recycling stations, garden waste, sludge from septic tanks, and recycled paper and cardboard. The quantity of biodegradable waste in Tórshavn, the capital of the Faroe Islands, is quite small. Agriculture in the Faroe Islands is minimal due to a lack of land and the limited waste that is generated within the meat industry is incinerated. The bulk of biodegradable waste currently generated in the Faroe Islands is either used as a fertiliser or composted. The biggest opportunities for increased utilisation lie within the fishing industry and increasing composting of biodegradable waste generated in households.

Iceland

The main sources of biodegradable waste in Iceland are garden waste, animal carcasses, the fishing industry, the meat industry, sludge from septic and sewage systems, canteens and kitchens, manure from domestic animals, and agricultural and forestry waste. The largest sources are the meat industry and garden waste. Approximately a third of the biodegradable waste generated yearly is either landfilled or incinerated. Two thirds are re-used or recycled in different ways, such as production of animal feed, composting, production of biodiesel, and landscaping at landfill sites.

The three maps below show the distribution of the biodegradable waste in Iceland, based on data from waste receiving stations. The green map shows the distribution of all biodegradable waste generated in Iceland. The map shows that most waste is generated in the capital region and the northern part of the country. The blue map shows waste from the fishing industry, demonstrating a pattern similar to the green map. The red map shows biodegradable waste generated from the meat industry, with most of it generated in the northern part of the country. 


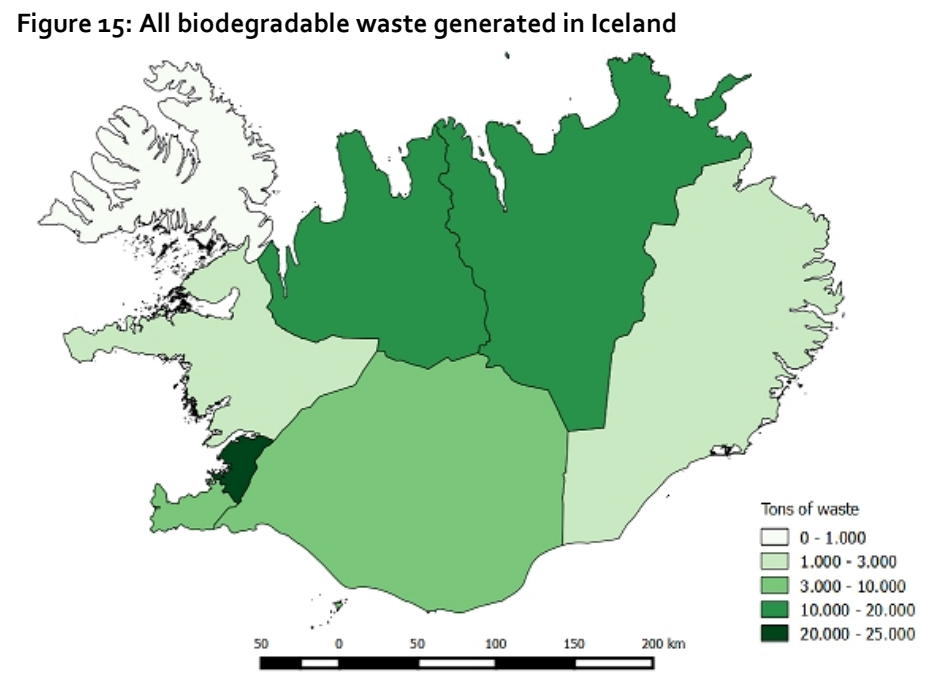

Figure 16: Biodegradable waste from the fishing industry

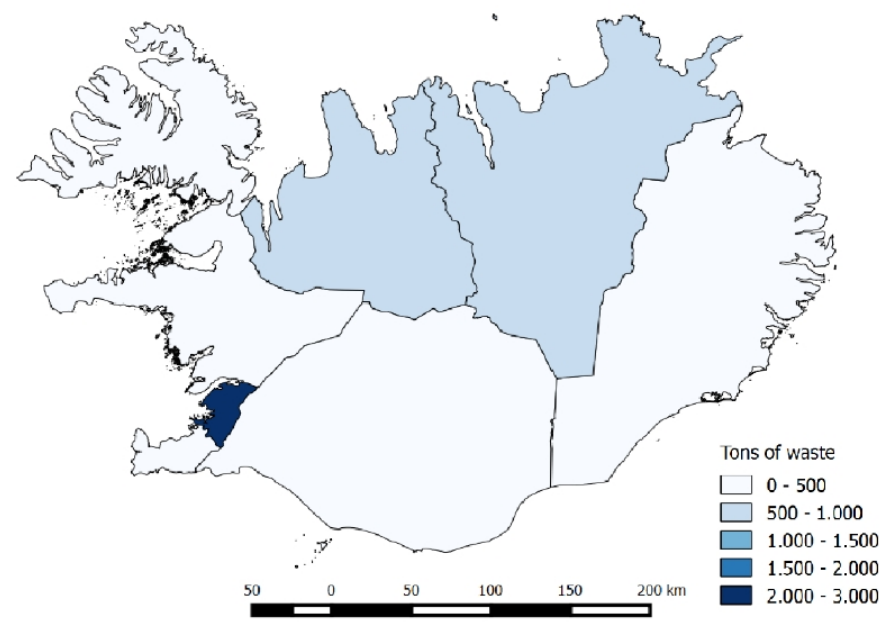

Figure 17: Biodegradable waste generated from the meat industry

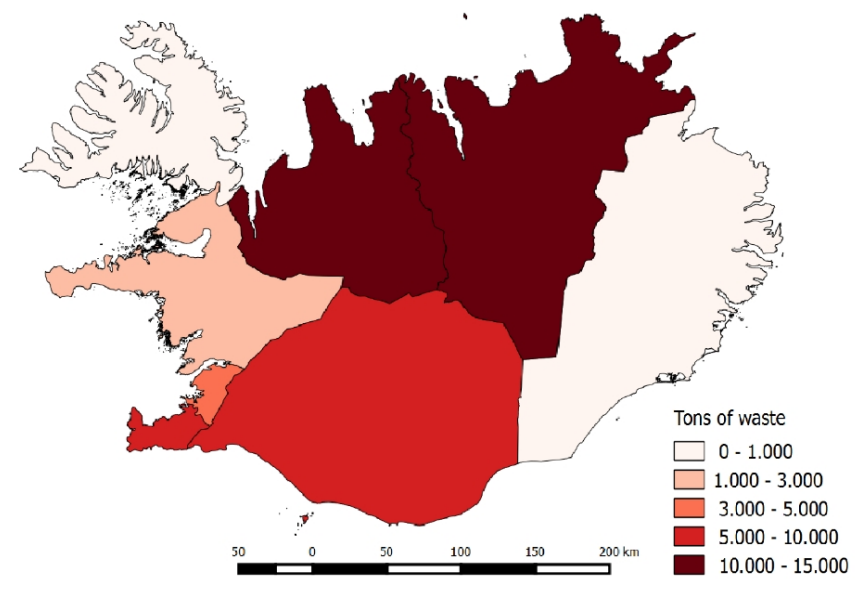


It is important for innovators, entrepreneurs and those who intend to utilise the waste to know where, when, and in what quantity the waste or potential resource is generated. Therefore, more detailed and more frequent data collection is needed. The biggest challenge identified with utilising biodegradable waste is obtaining the resource and securing a steady supply. Increased data collection would minimise this uncertainty and thereby reduce the risk of investing in green innovation.

\subsubsection{Main conclusions}

The main conclusion of the project is that there is a significant lack of data on biodegradable waste in Greenland, the Faroe Islands, and Iceland. Nevertheless, it is evident that biodegradable waste is an underutilised resource in these countries. Therefore, there are numerous opportunities for increasing the utilisation of this resource and thereby reducing the generation of waste and promoting a more sustainable economy. Increasing the utilisation of this resource has both economic and environmental benefits.

For this to be possible, it is vital to provide information on where, when, and by whom the waste is disposed. One of the main challenges associated with utilising biodegradable waste are difficulties in obtaining the resource. There seems to be a missing link between those who generate waste and those who can utilise it. In addition to increasing data collection on biodegradable waste, it is important to create this missing link.

In order to create a connection between the industries involved in generating biodegradable waste and those who can utilise it, a web-based marketplace for biodegradable waste and by-products was developed by the Environment Agency of Iceland, called the Resource Square (in Icelandic: Auðlindatorgið). ${ }^{4}$ Industries can advertise their by-products and innovators can ask for specific material on the marketplace. Thereby, the marketplace creates the missing link between industries and potential users, while also promoting increased utilisation of natural resources and reducing waste.

Figure 18: The banner of the Resource Square (in Icelandic: Auðlindatorgið)

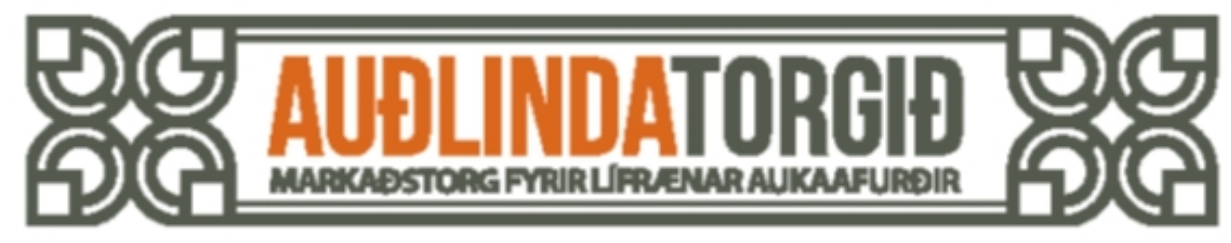

4 See: http://audlindatorg.is/ 


\subsection{Regional economic impact and potential of Nordic Bioeconomy}

\subsubsection{Main objectives}

The purpose of the project was to prepare an in-depth analysis of regional economic impact and potential of the Nordic bioeconomy, with a focus on selected case study regions. The Input-Output analysis was applied in an experimental fashion to try to capture the economic and labour market linkages between the bioeconomy sectors and the rest of the regional, national and global economy in these regions. Based on this knowledge, a scenario based analysis regarding the impact of expansion of the bioeconomy in the future in the case study regions was developed. Finally, the goal was to develop a research methodology to be applied in further studies on the regional economic potential of the bioeconomy.

\subsubsection{Implementation}

The project was implemented by Nordregio and Innovation Center Iceland. For analysing regional direct and indirect economic impacts, a methodology of InputOutput analysis was implemented in a regional case study context. Input-Output accounting is a method for analysing the economic interactions between sectors in an economy and for calculating "multipliers", which indicate the potential of a sector or product to stimulate a wider economic impact.

The national input-output tables were used to construct a set of regional tables for the regions studied in order to calculate production multipliers and employment multipliers. This resulted in a deeper understanding of the regional impacts of developments within the bioeconomy and associated sectors. Obviously, the regional production and employment multipliers are much lower than the national multipliers. The reason for this is that in a region not all commodities used as inputs to various forms of production are produced within the region.

Seven Nordic case study regions were chosen for the regional bioeconomic potential study: Värmland in Sweden, Central Finland region in Finland, Buskerud in Norway, Zealand in Denmark, and Northwest Iceland and Reykjavik regions in Iceland. Moreover, the study includes a discussion on evaluation of regional economy potential of bioeconomy in Åland, although this island is not a part of the input-output analysis. The case study analyses include a qualitative analysis based on the review of the existing reports and interviews with the representatives of the key actors and interest groups in the regions. The regional case study reports provide an important "doublecheck" on the Input-Output figures and are essential for understanding the nature and potential of bioeconomy in the regions.

Due to the fact that the EUROSTAT data is not available in Iceland, the quantitative analysis on national and regional bioeconomy was more difficult to implement there compared to Finland, Sweden, Norway, and Denmark. 


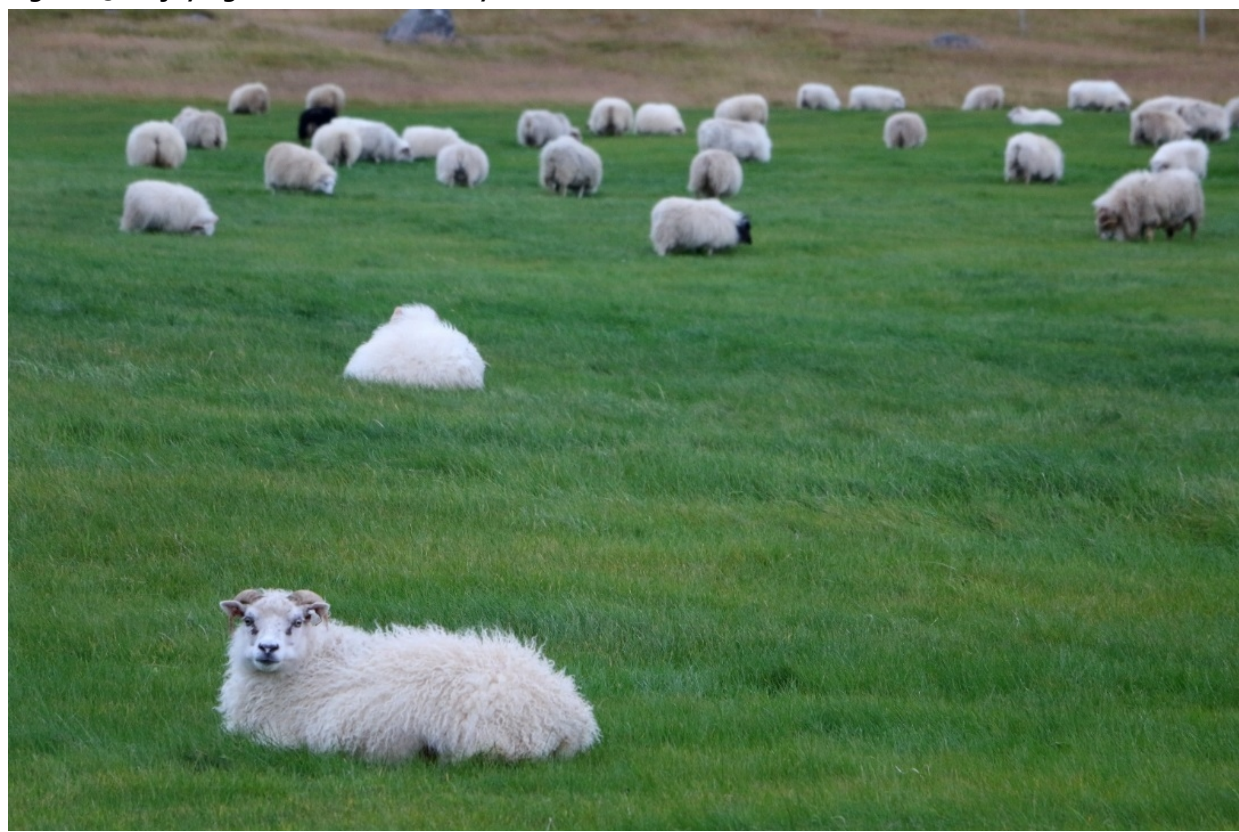

Source: Hugi Ólafsson.

\subsubsection{Main conclusions}

In the examined regions, the highest regional multipliers generally refer to agricultural, food industry and wood products. Agriculture has high multipliers, and this gives the food industry high multipliers, because expansions in the food industry will imply more agricultural products being produced. The "new" (or associated) bioeconomy sectors have lower multipliers - largely due to the fact that they are not really interacting with the primary sectors as of today. Developing "new" isolated bioeconomy sectors would not boost the regional economies in which they are embedded. Instead, in order to contribute to the regional multiplier impacts, the associated sectors need to grow in an integrated fashion with the use of the regional bioresources.

National bioeconomy sectors, and associated sectors, have multipliers between 1.5 and 3. At the regional level, impact is usually in the magnitude of 1.1 to 1.5 . If the regional multiplier effect is perceived to be 1.1 or 1.3, it still makes a big difference; in the first instance an expansion of a sector implies a 10\% additional impact on the regional GDP, while in the latter a $30 \%$ additional impact. But, it is difficult to compare regional economies straight-off since regions differ in size; however, it is interesting to observe that the studied regions do not display as clear patterns as do the countries (e.g. for Finland and Norway).

Among the most important conclusions is that there needs to be an integrated bioeconomy development in the Nordic regions, since in order to capture regional multiplier impacts there needs to be utilisation of regional resources which stimulates other regional sectors and creates regional employment. 
In order to estimate the future potential of the bioeconomy in the Nordic regions when it comes to "kronas/euros and jobs", the exploratory attempt to use scenario analysis appeared to be a highly interesting and promising method. Although definite answers or guidance on the Nordic bioeconomy's future potential are difficult to derive from the scenario analysis, the introduction of the method reveals what kind of scenarios need to be pursued and analysed further, and what can be framed in the context of the regional economic analysis. 


\section{The Nordic Bioeconomy Panel}

The Nordic Bioeconomy Panel is a formal policy and strategy forum set up by the Ministers for Nordic Co-operation (MR-SAM). The panel was established as a part of the NordBio program in 2014, during the Icelandic Presidency of the Nordic Council of Ministers. Setting up the panel reflects the importance that the Council of Ministers attaches to a forum that focuses on holistic thinking about promoting the bioeconomy.

\subsection{Objectives}

The Panel's objectives are to:

- contribute to a sustainable transformation towards the bioeconomy in the Nordic countries and to stimulate innovation

- explore and expose the potential of the Nordic region to take a global lead in the field of sustainable development production and utilisation of bioresources with the purpose of enhancing both the competitiveness and sustainability in the Nordic countries.

The objectives will be achieved through a joint Nordic bioeconomy strategy, by including new, cross-sectoral knowledge and by contributing to the Nordic countries and relevant Nordic and international forums regarding innovative thinking and solutions to the challenges the countries are facing in relation to the bioeconomy and green transition.

\subsection{Members}

The panel consists of a diverse group of representatives of official agencies, research bodies and private companies. Collectively, they provide insight into socioeconomics, natural science, business, regional policy and the environment, and represent each Nordic country. Members of the European Bioeconomy Panel are invited to observe the panel's meetings, as well as many other different observers from the Nordic institutions. ${ }^{5}$

${ }_{5}^{5} \mathrm{~A}$ list of members and observers can be found on this website: http://www.norden.org/en/theme/nordicbioeconomy/nordic-bioeconomy-panel/members-of-the-nordic-bioeconomy-panel 


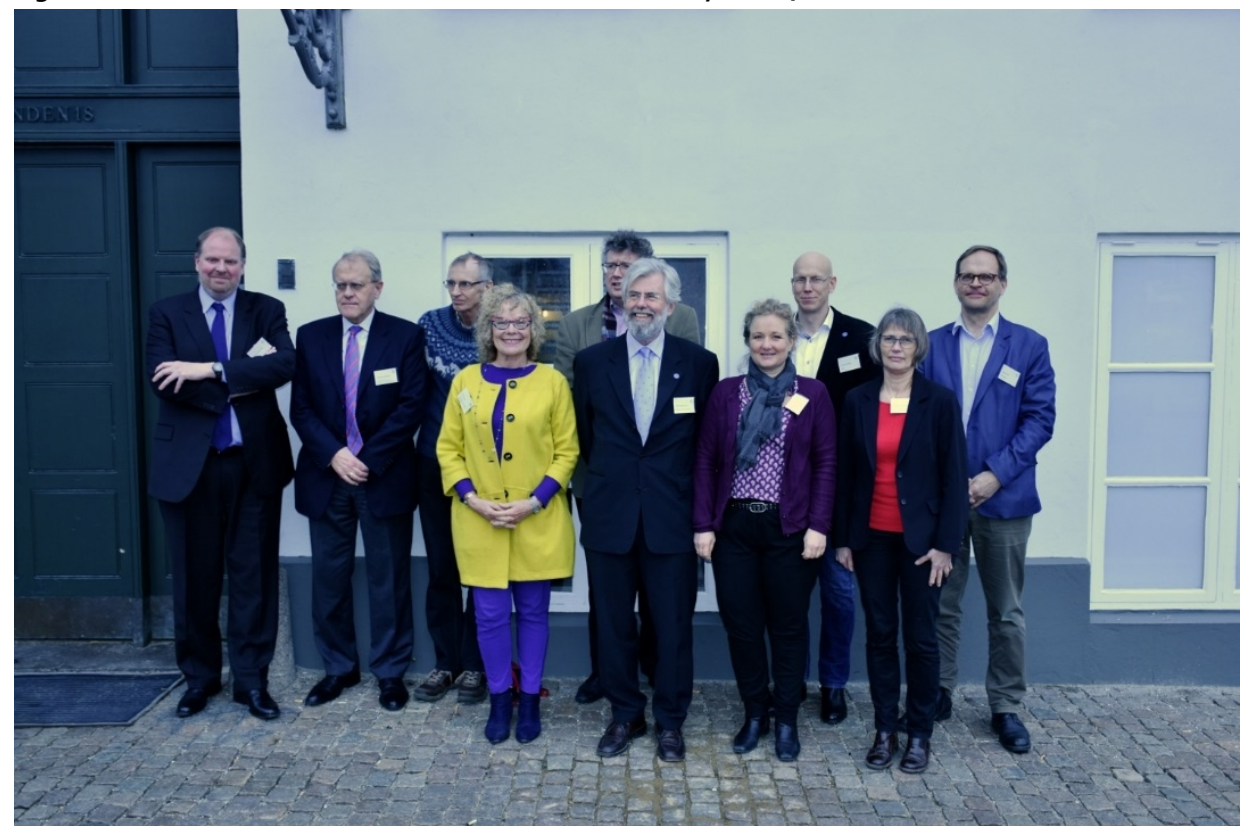

Source: Torfi Jóhannesson.

\subsection{Budget and timeline}

The mandate of the panel covers a two-year project (2016-18) and the expenses are provided by the Icelandic chairmanship (2014). The budget accounts to DKK 1,900,000 and includes a half-time project secretary for the two years, who is hired by the Nordic Council of Ministers. When the two-year project comes to an end there will be an evaluation to decide the future of the panel.

The first meeting of the panel was held in March 2016 in Copenhagen, the second in October 2016 in Reykjavik, the third in February 2017 in Oslo, and the fourth meeting will be in April/May 2017.

\subsection{Main tasks}

The panel's main job is to draw up proposals for a Nordic strategy for the bioeconomy, outlining options and practical measures to promote sustainable bioeconomies. The strategy proposal will be developed in close cooperation with national bioeconomy panels of the Nordic countries and will take into account previous experiences gained from their bioeconomy initiatives. The strategy should include measures that relate to production in all sectors of the bioeconomy, such as agriculture, forestry, fishing and hunting, as well as processing and consumption. The main purpose of the strategy is to describe the possibilities to promote and coordinate Nordic cooperation in the field of 
bioeconomy, and to have influence on political decisions in the Nordic countries in the years to come. The first strategy proposal will be delivered to the ministers for Fisheries and Aquaculture, Agriculture, Food and Forestry in June 2017. The final proposal will be delivered to the ministers for Co-operation in October 2017 and is expected to be published in December 2017.

The second concrete task for the panel is to assemble a "best cases catalogue", a compilation of around 20 specific examples of success stories from the bioeconomy development in the Nordic countries. The catalogue "Nordic Bioeconomy: 25 cases for sustainable change" was published on 19 January 2017 at a stakeholder conference in Copenhagen. The catalogue is made in collaboration with the Danish think thank Sustainia. Together with Sustainia and the Nordic Council of Ministers, the Nordic Bioeconomy Panel developed a set of sustainable criteria for the selection of the cases with the purpose to make a transparent and coherent evaluation of the cases and claiming the need for a holistic sustainable development. The panel finally selected 25 cases to illustrate four "strongholds" of the Nordic bioeconomy: replace, upgrade, circulate and collaborate. ${ }^{6}$

The panel is also asked to ensure networking, create a network with relevant stakeholders and a strong outreach about the Nordic Bioeconomy. Both the chair of the panel, Hörður Kristinsson, and the secretariat has therefore made a number of presentations about the panel and its work at Nordic and international conferences and meetings. Furthermore, the outreach of the best cases catalogue has been very successful, with 4,500 visits on the website just within the first 10 days.

The secretariat and the panel also hosted a stakeholder workshop in January 2017 to ensure networking and dialogue with relevant stakeholders. Fifty stakeholders participated and provided input to the work with the strategy. The stakeholders represented many different sectors, were from both private and public sector, and represented all the Nordic countries, including Greenland and the Faroe Islands.

${ }^{6}$ The publication can be found at https://doi.org/10.6027/ANP2016-782 



\section{Minding the Future}

The closing conference of the NordBio program "Minding the Future - Bioeconomy in a Changing Nordic Reality" took place in Reykjavik, Iceland on 5-6 October 2016.7 The agenda consisted of presentations and discussions on various subjects related to bioeconomy, as well as interactive breakout sessions dedicated to different aspects of the theme.

The conference brought together experts on the bioeconomy with diverse backgrounds and from various countries, including Iceland, Norway, Denmark, Germany, Finland, and the United States. The purpose of the conference was to offer an informative and inspiring dialogue, present the outcomes of the NordBio projects, discuss challenges and opportunities ahead and to sow new seeds for the future.

The conference also featured the premiere of the NordBio Video, which introduces the concept of bioeconomy in a clear and graphical manner and presents bioeconomy activities performed during Iceland's presidency of the Nordic Council of Ministers. ${ }^{8}$

\subsection{Agenda}

Wednesday, 5 October, 09:00-16:30

The first day of the conference was divided into one plenary session and four break-out sessions. The plenary session began with opening remarks by Gunnar Bragi Sveinsson, Minister of Fisheries, Agriculture and Regional affairs in Iceland, and Dagfinn Høybråten, Secretary General of the Nordic Council of Ministers. Their remarks were followed by the premiere of the Bioeconomy Video and presentations of three keynote speakers:

- Dr. Christine Lang, Chairwoman of the German Bioeconomy Council and CEO of Organobalance $\mathrm{GmbH}$

Bioeconomy and the future of biological resources.

- Dr. Ari Kristinn Jónsson, President of Reykjavik University

Education and innovation for sustainable bioeconomy.

\footnotetext{
7 See the conference webpage: http://nordbio2016.yourhost.is/

8 The video is accessible at http://www.norden.org/is/a-doefinni/myndskeid/icelands-presidency-in-the-nordic-council-of-

ministers-the-nordbio-video
} 
- Dr. Lene Lange, Professor, Department of Chemical and Biochemical Engineering, Technical University of Denmark How to unlock the full potentials of the biomass.

The break-out sessions, which each lasted half an hour, were dedicated to the following topics.

Session A: Minding future disasters

Panel discussion between the media reporter Póra Arnórsdóttir and the following experts:

- Guðmundur Halldórsson, Coordinator of the ERMOND project, Soil Conservation Service of Iceland.

- Ásdís Hlökk Theodórsdóttir, the Icelandic National Planning Agency.

- David Finger, Reykjavik University.

- Ólafur Arnalds, the Agricultural University of Iceland.

- Sigrún Karlsdóttir, the Icelandic Met Office.

- Jannes Stolte, Bioforsk, Norway.

The Minister for the Environment and Natural Resources in Iceland, Mrs. Sigrún Magnúsdóttir, addressed the workshop and gave an account of the signature of an agreement for Hekluskógar reforestation project.

Session B: Minding our business

Panel discussion based on short presentations from the following experts:

- Lene Lange, Technical University of Denmark Multiple value streams from biomass - the cascading approach.

- Hörður G. Kristinsson, Matís

New markets and products: opportunities and hurdles.

- Ingunn Gunnarsdóttir, Environment Agency of Iceland Waste as a resource for innovation.

- Hólmfriður Sveinsdóttir, Iceprotein

Regional impact of innovation in the Bioeconomy.

Session C: Minding future education

A mapping exercise on the topic of future education and the role of education in raising awareness of environmental challenges. The exercise was led by led by Dr. Bryan Alexander, a futurist, researcher, writer, speaker, consultant and teacher. 
Session D: Minding future divestment

Discussion between participants on the concept of fossil fuel divestment. The workshop was facilitated by the media reporter póra Arnórsdóttir and included special inputs from the following experts:

- Hallstein Havåg, Bellona Foundation, Norway.

- Annie Bersagel, KLP Kapitalforvaltning AS.

Thursday, 6 October, 09:00-12:30

The second day of the conference was a half-day plenary session which began with three keynote speaker presentations:

- Dr. Brynhildur Davíðsdóttir, Professor of Environment and Natural Resources, University of Iceland

Nordic natural capital: the foundation for blue and green growth.

- Dr. Bryan Alexander, educator, futurist, speaker and writer How education can help us build sustainable societies?

- Dr. Hörður Kristinsson, Chairman of the Nordic Bioeconomy Panel Role and plans of the Nordic Bioeconomy Panel.

The plenary session continued with two sets of short presentations. In the first one, Liisa Saarenmaa, Ministry for Agriculture and Forestry, Finland, and Ásmundur Guðjónsson, Director for Nordic Atlantic Cooperation - NORA, talked about bioeconomy projects under Denmark's and Finland's chairmanships of the Nordic Council of Ministers.

In the second set, Ásdís Ólafsdóttir, Communications Officer at the EFTA Surveillance Authority, and Haraldur Hugosson, Project Manager at Icelandic Startups, each made remarks under the topic description "Voices of a new generation".

Following a summary and closing of the conference, guests were invited to attend an exhibition where about 50 innovation projects were displayed and new products showcased. The projects were carried out with local producers in the West Nordic region focusing on innovation and increased sustainability of food production, utilising better bioresources and creating new value from side streams of food processing. 


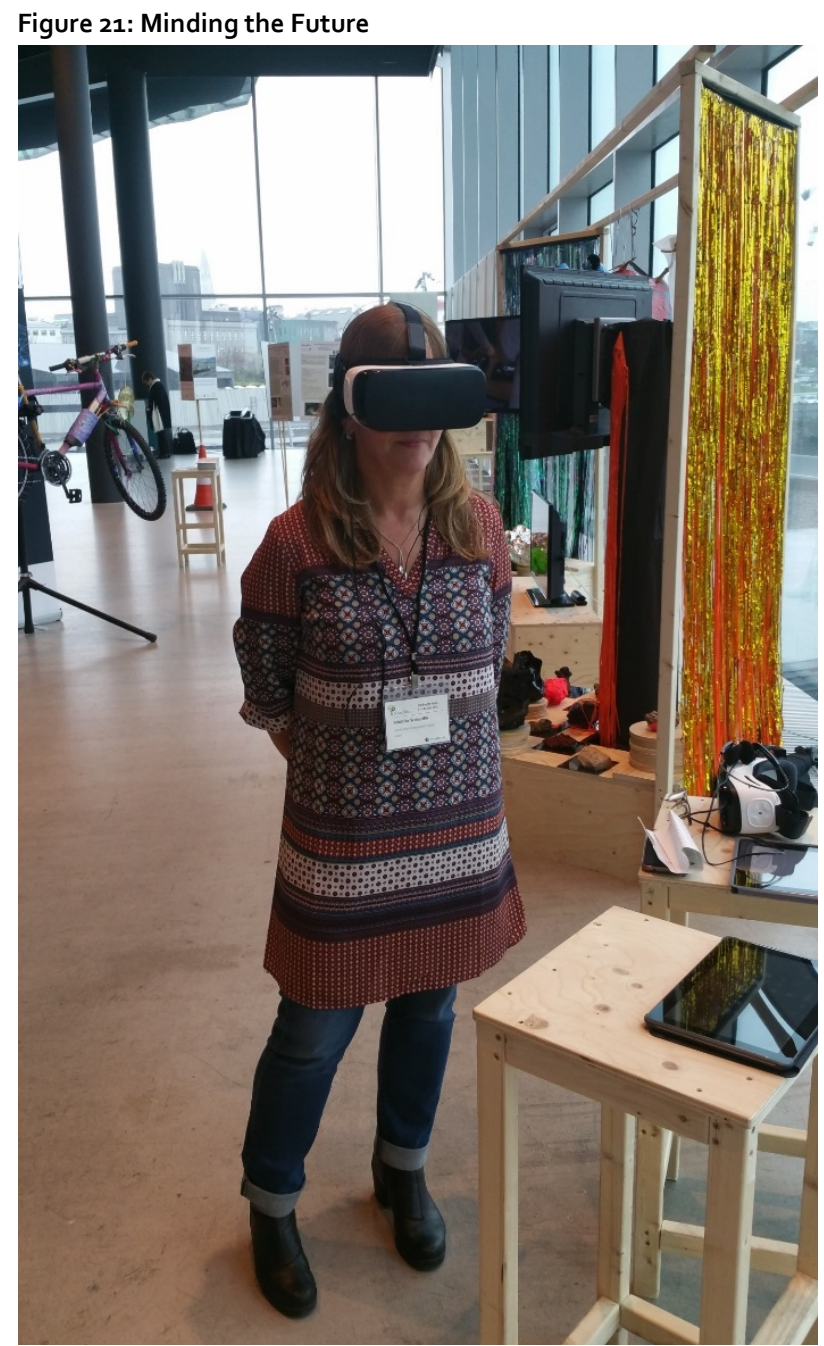

Source: Matís/Steinar B. Aðalbjörnsson.

\subsection{Highlights from presentations}

\subsubsection{Main topics}

The presentations and discussions covered a wide range of topics, offering an overview of the current development of the bioeconomy in the Nordic countries. Many opportunities were discussed, including product development based on sustainable and optimised use of biological resources. Among other topic issues were the need for improved definitions and mapping of the Nordic bioeconomy, the importance of capacity building and innovation in education, and the need to strengthen ecosystem resilience to reduce the impact of natural disasters. The presentations provided insights into various challenges and obstacles that need to be addressed in order to develop and 
strengthen the bioeconomy. One of the most important challenges, according to many of the speakers, is to find ways to better communicate the social and economic benefits of bioeconomy development to both politicians and the public, in order to influence political decisions and behaviour in the years to come.

Many speakers highlighted the successes of the Nordic countries in different fields of the bioeconomy and expressed the view that these countries should lead the way towards a global bioeconomy. That can be done in many different ways, such as by sharing knowledge and experiences and by participating directly in bioeconomy development projects in other countries. Significant emphasis was placed on the role of education and the reforms that are needed to infuse sustainability focus, creativity, and innovative thinking into the curriculum of every educational stage, as well as into the continuing education of professionals.

\subsubsection{Opening statements}

In the first opening statement, Mr. Gunnar Bragi Sveinsson, Minister of fisheries, agriculture and regional affairs in Iceland, highlighted the importance of efforts to make best possible use of the planet's biomass and biological resources in a sustainable way. Noting the rich traditions of food production and food science in the five Nordic countries, Mr. Sveinsson expressed the view that these countries are particularly well suited for collaboration in the new area of the bioeconomy. He concluded by mentioning the successes of Icelandic ocean-based biotechnology companies and Iceland's good reputation relating to its sustainable, effective, and highly technological fisheries industry, emphasising the important role of the country in international cooperation in the field of the blue bioeconomy.

In the second opening statement, Mr. Dagfinn Høybråten, Secretary General of the Nordic Council of Ministers, reflected on the common Nordic history and spoke about the importance of bioresources for the Nordic economies. He noted that although the Nordic countries have in many ways been successful in managing their natural resources, they are faced with various challenges. As an example, he mentioned export of resources without sufficient economic value being added, as well as loss of skills and jobs to other parts of the world, resulting in increased uniformity of Nordic regional economies and fewer opportunities for young educated people, especially women. Mr. Høybråten applauded the NordBio program as an important initiative to change this development, having already succeeded in putting the term bioeconomy on the political agenda in the Nordic countries, and having mobilised other Nordic institutions to launch activities to stimulate the transition to bioeconomy in the Nordic countries.

\subsubsection{Christine Lang}

In the first keynote speaker presentation, Dr. Christine Lang, Chairwoman of the German of Bioeconomy Council and CEO of Organobalance $\mathrm{GmbH}$, talked about the bioeconomy and the future of biological resources. Dr. Lang gave a general introduction to the concept of the bioeconomy and its sources, paying special attention 
to the importance of microorganisms. She spoke about various challenges the bioeconomy faces, including overpopulation, unsustainable modern consumption patterns, waste, soil degradation, overutilisation of resources and loss of global biodiversity. To meet these challenges, she said, the bioeconomy needs to be placed at the center of efforts relating to sustainable development, both at national and international level. The bioeconomy could thus create a link between the conflicting goals of food security, climate change mitigation, and ecosystem conservation. For that to happen, the bioeconomy needs to be the cornerstone of other goals, such as the UN's Sustainable Development Goals.

Dr. Lang explained how perspectives on bioeconomy policies have changed since the term "bioeconomy" first became part of public discussion around the year 2005 . Initially, biomass was primarily seen as a potential solution to the problem of oil scarcity and rising oil prices, serving as a substitute for fossil fuels. This has changed, and bioeconomy, biotechnology and innovation are, according to Dr. Lang, recognised as drivers for the necessary development towards carbon neutrality and sustainability.

Noting that Germany is not very rich in biomass, Dr. Lang talked about how its bioeconomy strategy has been knowledge-based and primarily aimed at adding value to biomass in areas such as agriculture and energy. The main contribution of Germany to the global economy should, in Dr. Lang's view, continue to consist of new ideas and knowledge and the development of new processes and products.

Dr. Lang stated that in addition to technology innovation, social innovation is a key factor for sustainable bioeconomy development. She stressed the importance of public participation in policy-making, both in Germany and elsewhere in the world. In her view, people need to be better informed about the role of biotechnology in solving the challenges facing the world, such as the need to replace fossil fuels. Dr. Lang provided several examples of product innovations in Germany which could be used to introduce biotechnology to people, including biomaterial in the car industry, biobased building materials, enzymes for washing and personal care and microorganisms in cosmetics and food. She concluded by mentioning a number of bioeconomy policies that are being developed in different parts of the world, and briefly introduced the work of the Global Bioeconomy Summit.

\subsubsection{Ari Jónsson}

In another keynote presentation, Dr. Ari Jónsson, President of Reykjavik University, highlighted the importance of education and innovation for a sustainable bioeconomy. He began his talk by emphasising the important role of the bioeconomy as the key to long-term sustainability. While acknowledging that real progress has been made in many areas, he noted that the world still has a long way to go. In this context, he mentioned problems such as overuse of natural resources, inefficiency of processes, ecological pressures caused by energy production and use, and the fact that human behaviour is generally still unsustainable.

Dr. Jónsson noted that in order to make progress, manpower and education have to be at the forefront, and he stressed the importance of ensuring the right mix of 
education, as well as innovation training and a supportive environment. He mentioned a few well-known examples which can serve as drivers in how to approach bioeconomy development, such as the drastic changes in the information technology industry during the last few decades, and progress in the biological area. He also talked about the value increase in the Icelandic fisheries industry, noting that while the amount of fish caught in 2011 was less than half of what it was in 1984, its value had more than doubled. He explained how many different things must come together to create these successes, such as need, expertise, innovation, and a supportive environment.

In Dr. Jónsson's view, all these factors need to be taken into account when talking about the role of education and innovation for the bioeconomy. He emphasised that instead of relying on traditional education in science and technology, people also need to be trained from the beginning in innovative thinking. Furthermore, an interdisciplinary approach is vital to ensure that the manpower can connect between areas. Dr. Jónsson pointed out that there are many ways of doing this, such as problem-based learning, innovation classes, and interdisciplinary programs that are specifically focused on particular subjects such as fisheries. Finally, he noted that innovation cannot focus on the product in question, but has to take every aspect of the solution into account, including the new processes, technology, connections, products, and marketing.

Dr. Jónsson concluded by noting that both Iceland and the other Nordic countries are excellent places to use as test beds for new sustainable products, and thus make it easier to convince people to accept them. That, however, calls for an understanding from the governments and requires adequate funding. Finally, Dr. Jónsson reiterated that if the know-how and education, inspiration, capacity and the right environment for driving innovation are all brought together, real progress can be made in moving towards a sustainable bioeconomy and a sustainable world.

\subsubsection{Lene Lange}

In the last keynote speech of the first day, Dr. Lene Lange, Professor, Department of Chemical and Biochemical Engineering, Technical University of Denmark, raised the question of how to unlock the full potentials of biomass. She began her presentation by discussing the benefits of the bioeconomy and its potential role in climate change mitigation, in feeding the world, and in stopping loss of biodiversity. She underscored the importance of improved resource efficiency and noted that neither the public nor politicians are aware of the economic possibilities associated with making better use of natural resources. Noting that at least $30-40 \%$ of everything that is produced is wasted, she explained how upgrading the use of natural resources could make it possible to feed the rapidly increasing global population, as well as to build the economy, create jobs etc. Upgrading waste and residues is important as well, particularly increasing animal feed production which would have the result of freeing land for food production and to support increased biodiversity.

Dr. Lange gave an overview of several projects in each of the Nordic countries which she considers to be an important contribution to the bioeconomy in the region, including small scale green biorefineries, blue biorefineries, macroalgae, export of 
healthy food, and upgrade of household waste. She also mentioned potential new opportunities for the Nordic countries, focusing on Greenland and Denmark, and briefly described the priority projects recommended by the Danish Bioeconomy Panel. She furthermore drew attention to the significant potential of the bioeconomy in reducing $\mathrm{CO}_{2}$ emissions, particularly by using sustainable biomass to substitute fossil fuels.

Dr. Lange concluded her presentation by proposing that the Nordic countries take the initiative to reduce regulatory obstacles within the EU for bio-based products. She encouraged the countries to work together in building markets for bio-based products, seek funding opportunities, and collaborate on bioeconomy projects further afield in Africa, Eastern Europe and the Baltics. She reiterated that the Nordic countries should be leading in developing the bioeconomy and urged the conference guests to communicate its social and economic benefits to the public and policy-makers.

\subsubsection{Brynhildur Davíđsdóttir}

In the first presentation of the second day, Dr. Brynhildur Daviðsdóttir, Professor of Environment and Natural Resources at the University of Iceland, discussed Nordic natural capital as the foundation for blue and green growth. Dr. Davíðsdóttir began her presentation by explaining the concepts "natural capital" and "natural resources" and the difference between them. She explained how ecosystem services derived from the natural capital are classified into direct services, i.e. provisioning services such as natural resources, and indirect services, i.e. supporting and regulation services and cultural services. Noting that provisioning services have traditionally been divided into renewable and non-renewable resources, she pointed out that the bioeconomy focuses primarily on the renewable provisioning services. She also remarked that green growth, for a large part, takes place in new and unconventional uses in existing provisional services, and in indirect ecosystem services, such as tourism.

Dr. Daviðsdóttir gave a short historical perspective on the development of the green and blue economy and offered definitions of these concepts, as well as the concepts of green and blue growth. She stressed that the green economy is not a conceptual replacement for sustainable development, but a tool which can be used to achieve sustainable development.

Dr. Davíðsdóttir mentioned several major obstacles that need to be overcome in order to further develop green and blue growth. First, she addressed the significant lack of knowledge about the contribution of different natural capital types or environmental services to the green or blue economy, especially the indirect ones. Other challenges include degradation of natural capital due to overuse and mismanagement, insufficiency of sector-based management, and inability of traditional metrics such as GDP to capture the "whole picture". 
Figure 22: Brynhildur Daviððsdóttir giving her presentation at the conference

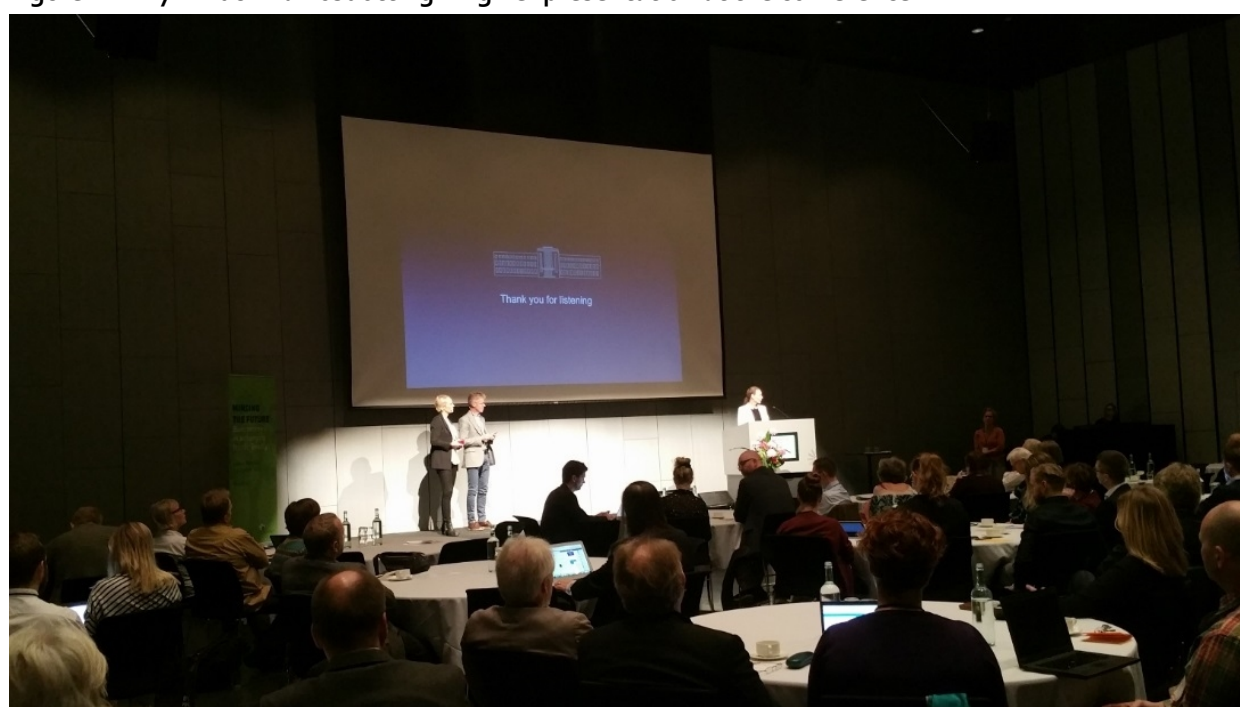

Source: Matís/Steinar B. Aðalbjörnsson.

Discussing how to address these challenges, Dr. Davíðsdóttir stressed the importance of setting clear, measurable and internally consistent goals and targets for a sustainable green and blue economy, and assessing and communicating the performance of these goals and targets using new metrics. She furthermore emphasised the need to classify, map spatially and assess natural capital and ecosystem services in order to manage them. She noted that sustainability standards, guidelines and best practices that support a green and blue economy need to be developed and applied.

Dr. Davíðsdóttir concluded her presentation by explaining how natural capital and ecosystem services could be mapped and assessed, and briefly described the framework adopted by the European Union, Mapping and Assessment of Ecosystem and their Services (MAES).

\subsubsection{Bryan Alexander}

Dr. Bryan Alexander, educator, futurist, speaker and writer, focused on education as a tool to help build sustainable societies. Dr. Alexander started his presentation by discussing the unsustainable state of the globe, and mentioned as an example that the global $\mathrm{CO}_{2}$ concentration level has now reached $400 \mathrm{ppm}$, although it needs to be limited to $350 \mathrm{ppm}$ to prevent the most serious consequences of climate change. Dr. Alexander talked about the risk of a vicious cycle created by factors such as political dysfunction, political unrest triggered by environmental stresses and escalating distrust and friction. He mentioned that while modern technologies provide many extraordinary benefits, they are far from being sustainable. He noted that computer production and disposal are expensive, carbon-intensive and heavily reliant on rare and hazardous earth materials.

Dr. Alexander raised the question of how education can respond to these challenges, and offered suggestions for steps that can be taken. He began by offering 
ideas about changes that can be made to the curriculum and pedagogy to make it focus on sustainability. The key in his view is to infuse sustainability across education, from primary school to universities and professional programs. This must involve ecological thinking and systems thinking, be interdisciplinary and emphasised on creativity and play. He furthermore emphasised that schools have to teach soft skills such as collaboration and participatory citizenship, focusing on democracy, living online, and the ethic of inclusion. In this context, Dr. Alexander talked about how democracy can change the environment of classrooms, libraries and civic areas. He also discussed digital literacy and the importance of scepticism, criticism, and future-thinking, and maintained that the best digital literacy is storytelling. He stressed the importance of open and accessible education resources and teaching, and outlined its benefits for both students and professionals. Finally, he introduced the idea of schools as sustainability sites, and discussed how students can be taught to analyse the environmental impact of the school itself and find ways to make it more sustainable.

\subsubsection{Hörður Kristinsson}

Dr. Hörður Kristinsson, Chairman of the Nordic Bioeconomy Panel, gave a presentation in which he described the objectives, history, composition and role of the panel. He spoke about the panel's foundation in the Nordic Bioeconomy Initiative, and how the cooperation aims at sustainable production and use of natural resources with focus on a cross-sectoral and systematic approach, with a basis in the circular economy.

Dr. Kristinsson described the main task of the Nordic Bioeconomy Panel, which is to draw up a proposal for a Nordic Bioeconomy Strategy. The strategy is intended to contribute to the sustainable transformation towards bioeconomy in the Nordic countries using a cross-sectoral approach. Its purpose is furthermore to influence the international and European bioeconomy agenda and to support the Nordic region as a global frontrunner within a sustainable and circular economy. Dr. Kristinsson stressed the importance of developing the strategy in close cooperation with national bioeconomy panels of the Nordic countries and building on the experiences of each country's bioeconomy initiatives.

In addition to composing a joint Nordic strategy, which the panel hopes to launch in the autumn of 2017, the panel is tasked with creating a "best cases catalogue" of the Nordic bioeconomy initiatives. The catalogue compiles examples of success stories with the view to spread inspiration and knowledge about the opportunities of the bioeconomy. The panel is furthermore committed to extending its network of experts and stakeholders and to foster a dialogue on national and European priorities. The panel has a strategy on how to reach out to the public, companies, academia, and very importantly, to policy-makers, thus seeking to influence national and local policies in the Nordic countries.

Dr. Kristinsson gave an overview of the bioeconomy strategies and main projects in each of the Nordic countries, noting that because of differences in priorities, resources and strengths, the countries will need to approach the bioeconomy in a different manner. He talked about the West Nordic Bioeconomy Panel, the purpose of 
which is to identify common key issues of importance for the West Nordic region, identify opportunities, advise industry, governments and the public, as well as to promote common key issues and policy.

Dr. Kristinsson's final message was that strategies alone are not sufficient; they must be put into action. It is therefore important that information about the bioeconomy is communicated to policy-makers and investors to make them aware of opportunities, and to influence their decisions.

\subsubsection{Other speakers}

Short presentations were given by Mrs. Liisa Saarenmaa, Director at the Finnish Ministry for Agriculture and Forestry, and Mr. Ásmundur Guðjónsson, Director for Nordic Atlantic Cooperation - NORA, on bioeconomy projects under the Danish and Finnish chairmanships of the Nordic Council of Ministers. Mrs. Saarenmaa talked about the Nordic roadmap for blue bioeconomy, which was being prepared under the Finnish chairmanship. She outlined the strategic goals of the roadmap, its themes and structure, and described the next steps toward its finalisation and adoption. Mr. Guðjónsson talked about the Faroese chairmanship in the Nordic fisheries cooperation in 2015, titled "Growth in the Blue Bioeconomy". He gave an overview of the project's main activities and events, including a high-level international conference held in Torshavn, Faroe Islands, in June 2015, where the blue bioeconomy was discussed in policy context, along with developments in the global blue bioeconomy, challenges in the marine industry, and barriers and incentives in developing the blue bioeconomy.

Finally, Mrs. Ásdís Ólafsdóttir, Communications Officer at EFTA Surveillance Authority, and Mr. Haraldur Hugosson, Project Manager at Icelandic Startups, made short presentations under the topic "Voices of a new generation". They talked, inter alia, about various challenges related to the realisation of the bioeconomy, and the need to address such challenges by promoting innovative solutions and knowledge sharing.

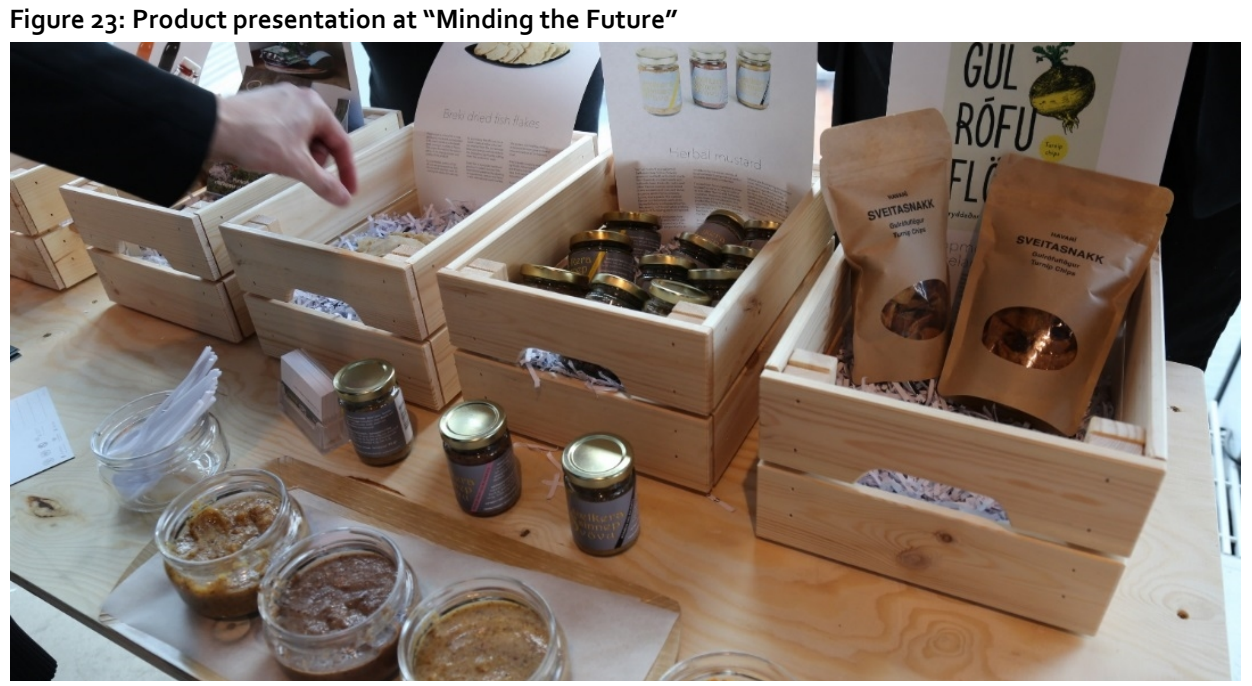

Source: Matís/Sigurður H. Guðjónsson. 


\subsubsection{Workshops}

Four interactive workshops discussed different aspects of the bioeconomy.

\section{Session A: Minding future disasters}

The workshop consisted of discussions between a media reporter and a panel of experts on the questions: Which changes in natural disasters can we expect in the future, and how can they be met to avoid potential disasters?

The general view of the panel was that we can expect a significant increase in natural disasters in the future. This calls for new solutions in disaster risk management. Primarily, a better integration of land use and disaster risk management is needed, and secondly, societies should aim at building up the resilience of ecosystems towards natural disasters.

\section{Session B: Minding our business}

The workshop consisted of presentations by four experts on the utilisation of by-raw materials (often referred to as "waste") and discussions on how a holistic approach of the whole value chain, including resources, sidestreams and markets in a changing society could improve resource efficiency and simultaneously create profitable businesses, with high regional, as well as global impact.

\section{Session C: Minding future education}

The workshop raised the question of what the future of education will look like, focusing on the crucial role education plays in raising awareness of environmental challenges and in shaping the behaviours and attitudes that can make a difference. The workshop was in the form of a mapping exercise, led by Dr. Bryan Alexander, who had the audience collaboratively identify new skills and content areas needed for students to succeed in the educational environment of the future.

\section{Session D: Minding future divestment}

The workshop addressed fossil fuel divestment and gave accounts of recent examples. The highlights of the discussion are outlined below.

\section{An example from workshop discussion: Minding future divestment}

The workshop focused on the now well-known concept of fossil fuel divestment, the challenges associated with adopting and implementing divestment policies, and the future of the trend. Two participants, Mrs. Annie Bersagel, Advisor in responsible investments at KLP Kapitalforvaltning AS in Norway, and Mr. Hallstein Havåg, Head of science and projects at the Bellona Foundation, a Norwegian environmental NGO, discussed their experiences related to divestment efforts in Norway.

Mrs. Bersagel offered insight into KLP's strategy for responsible investments. KLP, which is a large Norwegian pension fund manager, decided in 2014 to use fossil fuel divestment as one of the company's tools for responsible investments. Since then, KLP has divested from companies that obtain $30 \%$ or more of their revenues from coal power and coal mining. Mrs. Bersagel noted that the $30 \%$ threshold corresponds to the divestment criteria that the Norwegian Parliament adopted in 2015 for the Norwegian sovereign wealth fund (the Government Pension Fund). 
Mr. Havåg introduced Bellona's views and efforts regarding responsible and sustainable investments, including divestment. He underscored the importance of basing investment decisions on proper understanding of both the evolving markets of new technologies, including renewables, and the long-term risks of investing in past technologies such as fossil fuels. Mr. Havåg explained that although Bellona supports the recently adopted divestment policy of the Norwegian sovereign wealth fund, it has identified some issues that need further consideration. One major concern is the need to ensure that funds that are withdrawn from coal are put into good use elsewhere. Another concern is the negative impact that might result from divesting from all coal companies, without considering whether they plan to decarbonise their activities, for example by using carbon capture and storage.

A wide range of issues related to divestment were discussed in the workshop. The main takeaway from the discussion was that although examples from Norway and elsewhere indicate a growing interest in fossil fuel divestment, a number of significant challenges exist, affecting its feasibility as a tool for responsible investing. For example, Mrs. Bersagel mentioned the simple fact that selling stocks in a coal company unavoidably means that someone else will buy them. Divestment will thus not affect companies' liquidity unless it becomes a very widespread trend. Focusing on targeted investments might therefore, in Mrs. Bersagel's opinion, have more influence in stimulating the transition to a carbon neutral economy than divestment.

Another challenge lies in the reluctance of investors to pull their funds out of fossil fuels and invest in future technologies and assets. Mr. Havåg noted that the key to addressing this is to reduce the cost of capital for future technology businesses. Mr. Havåg talked about the need of creating incentives for companies to contribute to a carbon neutral future and emphasised the importance of identifying the technologies that are likely to proliferate. He pointed out that investors, as well as investment managers, need to acquire a better understanding of which future technologies are good investment opportunities. 



\section{References}

Danielsen, R. et al. (2016). The Nordic Bioeconomy. Sustainable utilisation of Bioresources in the Nordic Bioeconomy. University of Iceland, NordBio project number 14222.

Granhus, A., Hylen, G. \& Nilsen, J.E. (2012). Skogen i Norge. Statistikk over skogforhold og skogressurser I Norge registrert i perioden 2005-2009. Ressursoversikt fra Skog og landskap 03 (12).

Larsson, S., Lundmark, T. \& Ståhl, G. (2009). Möjligheter till intensivodling av skog. Slutrapport från regeringsuppdrag. Jo 2008/1885, SLU.

Lindberg, J.E. et al. (2016). Nordic Alternative Protein Potentials: Mapping of regional bioeconomy opportunities. Nordic Council of Ministers, TemaNord 2016:527.

McCormick K. \& Niina Kautto N. (2013). The Bioeconomy in Europe: An Overview, Sustainability 5(6), 2589-26o8.

Ministry of Agriculture and Forestry in Finland (2012). Year-book of Farm Statistics. Information Centre of the Ministry of Agriculture and Forestry.

Poulsen, G \& Solberg, S. Ø. (2015). Baltic Sea region: Mapping of regional potentials in protein supply from agriculture. Norden/Nordgen.

Rönnlund, I. et al. (2014). Creating value from bioresources: Innovation in Nordic Bioeconomy, Nordic Innovation Report 2014:01.

Smáradóttir, S.E. et al. (2014). Future Opportunities for Bioeconomy in the West Nordic Countries. Nordic Council of Ministers, TemaNord 2015:505.

Traustason, B. \& Gísladóttir, F. Ó. (2009). Hlutur skógræktar í ræktunarlandi framtíðarinnar. Fræðaping landbúnaðarins. 



\section{Sammanfattning}

Det Nordiska initiativet inom bioekonomi (NordBio) har varit ett samarbetsprogram som har involverat följande fem nordiska ministerråd: ministerrådet för fiskeri och havsbruk, jordbruk, livsmedel och skogsbruk (MR-FJSL); ministerrådet för miljö (MRM); ministerrådet för näringsliv, energi och regionalpolitik (MR-NER); ministerrådet för utbildning och forskning (MR-U); samt ministerrådet för kultur (MR-K). Programmet löpte av stapeln under det isländska ordförandeskapet i Nordiska Ministerrådet 2014 och sträckte sig över en treårsperiod (2014-2016).

Målsättningen med NordBio programmet var att de nordiska länderna skulle bli ledande inom den bioekonomiska utvecklingen. Programmet skulle även stimulera utveckling och framsteg inom hållbar produktion samt bruk av produkter, minska påverkan på miljön, stärka utbildning, kunskap och forskning inom det bioekonomiska fältet, främja nytänkande rörande effektiv energi, livsmedelssäkerhet och folkhälsa samt slutligen uppmuntra nordiskt samarbete.

Under NordBios paraply såg ett antal projekt dagens ljus som främjade NordBios målsättning. De olika projekten fokuserade på hållbart bruk av naturresurser och underlättande av uppbyggandet av konkurrerande ekonomi, samt utveckling av nya metoder inom utbildning av unga människor. Följande fem projekt var de "ursprungliga" eller "huvudsakliga" NordBio-projekten:

Biofilia Utbildningsprojektet - kreativitet $i$ klassrummet. Ett storskaligt pilotprojekt vars målsättning var att uppmuntra barn att undersöka deras egen kreativitet samtidigt som de lärde sig om musik, natur och vetenskap genom bruk av ny teknologi.

$E R M O N D$. Ett projekt som blev till för att underlätta nytänkande och uppmuntra nya lösningar för att öka ekosystemens motståndskraft för att förhindra skador och förlust av liv på grund av naturkatastrofer i de nordiska länderna.

Innovationer inom Nordisk Bioekonomi. Projektets mål var att ha direkt påverkan genom innovationer och värdeskapande inom Nordisk Bioekonomi samt stärka regional och ekonomisk tillväxt.

Nordic Marina. Målsättningen med detta projekt var att minska utsläpp och öka bruk av alternativa bränslen inom den marina sektorn.

WoodBio. Projektets målsättning var att lyfta fram skogsbrukets roll inom den Nordiska Bioekeonomin med särskild fokus på träbiomassa som råmaterial.

Ett flertal andra projekt och initiativ blev till under NordBios paraplyprogram, bland dem ett projekt vars mål var att kartlägga tillförsel av växtprotein till den nordiska livsmedels- och foderindustrin, ett annat projekt siktade mot att identifiera nordiska bio-resurser och omvärdera förvaltningen av dem, ett tredje projekt skapades för att stimulera innovation och värdeskapende inom bruk av biologiskt nedbrytbart avfall, ett fjärde projekt fokuserade på Nordisk Bioekonomis inverkan på regional ekonomi och dess potential. 
Utöver dessa projekt inkluderade NordBios initiativ etableringen av en ny Nordisk bioekonomipanel, ett tvärvetenskapligt konsultforum vars uppgift blir att utarbeta en gemensam nordisk strategi på bioekonomiområdet, förutom att uppmuntra och samordna nordiskt samarbete inom det bioekonomiska fältet.

Den avslutande konferensen inom NordBios program "Minding the Future Bioeconomy in a Changing Nordic Reality" ägde rum i Reykjavik, Island, den 5-6 oktober 2016. Konferensen sammanförde experter i bioekonomi med olika bakgrund och från olika länder. Målsättningen med konferensen var att erbjuda en informativ och inspirerande dialog, presentera resultatet av NordBios olika projekt, diskutera framtida utmaningar och möjligheter och så nya frön för framtiden. 
Nordic Council of Ministers

Ved Stranden 18

DK-1061 Copenhagen K

www.norden.org

\section{The Nordic Bioeconomy Initiative, NordBio}

The Nordic Bioeconomy Initiative, NordBio, was a cooperation program launched under Iceland's presidency of the Nordic Council of Ministers in 2014, with the aim to accelerate the development of a sustainable bioeconomy in the Nordic countries, and to enhance Nordic influence on European and global bioeconomy policies.

The NordBio program was based on cross-sectoral cooperation with the involvement of five Nordic Councils of Ministers and three governmental ministries in Iceland. One important result of this cooperation was the establishment of a Nordic Bioeconomy Panel, tasked with developing a common Nordic bioeconomy strategy, expected to be finalised before the end of 2017 .

This report is the final report of the NordBio program. It contains a summary of the main outcomes of the program, including its projects, the Nordic Bioeconomy Panel, and the closing conference of the program.

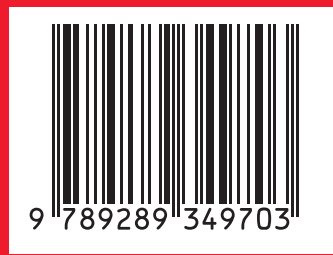

